\title{
Anti-hyperglyceamic Effects of Psidium guajava LINN Crude Leaf Extracts and Fractions in Alloxan- induced Diabetic Mice.
}

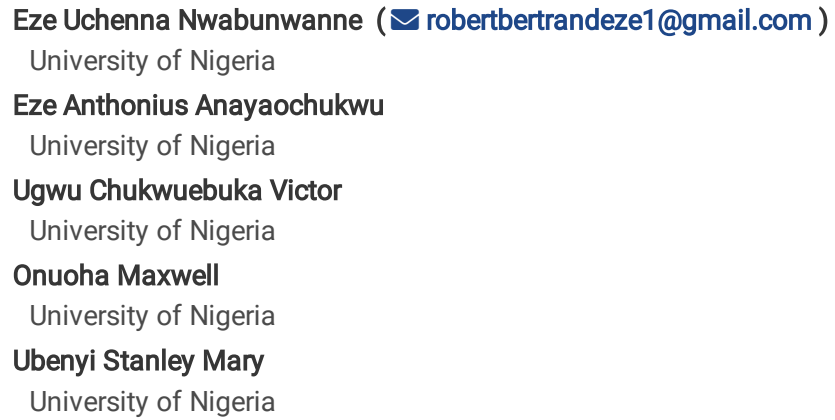

\section{Research Article}

Keywords: Type-2 diabetes mellitus, Psidium guajava, Anti-hyperglycemia activity, Phytochemicals

Posted Date: August 20th, 2021

DOI: https://doi.org/10.21203/rs.3.rs-812096/v2

License: (c) (7) This work is licensed under a Creative Commons Attribution 4.0 International License. Read Full License

Version of Record: A version of this preprint was published at Journal of Chemistry and Nutritional Biochemistry on August 31st, 2021. See the published version at https://doi.org/10.48185/jcnb.v2i2.283. 


\section{Abstract}

In Nigeria, rural inhabitants often resort to herbal remedies and dietary control for the treatment and management of various forms of diabetes mellitus. This study was conducted to provide the rationale for the use of Psidium guajava leaves as a potent traditional antidiabetic remedy. The crude leaf extracts of $n$ hexane, methanol, and ethyl acetate of Psidium guajava were separately prepared by cold maceration. Then, the ethyl acetate crude extract of Psidium guajava leaves was fractionated by column chromatography to yield ethyl acetate bulked fractions: EF-I (1-75), EF-II (76-150), and EF- III (151-250). The nhexane, ethyl acetate, and methanol crude leaf extracts and ethyl acetate bulked fractions (EF-I, EF-II, and EF-III) were evaluated for antidiabetic activity in alloxan-induced diabetic mice. The blood sugar levels of treated and untreated alloxan-induced diabetic mice were assayed as indices of antidiabetic effect. The phytochemical constituents of both crude extracts and ethyl acetate fractions of Psidium guajava leaves and the mean lethal dose (LD50) of ethyl acetate crude leaf extract of Psidium guajava were determined. The mean lethal dose (LD50) of ethyl acetate crude leaf extract was calculated to be $1500 \mathrm{mg} / \mathrm{kg}$ b.w. The results indicated that oral administration of ethyl acetate, $\mathrm{n}$-hexane, methanol crude extract, and ethyl acetate bulked fractions of Psidium guajava leaves at a dose of $100 \mathrm{mg} / \mathrm{kg}$ b.w on treated groups exhibited much significant $[p<0.001, p<0.01$ and $p<0.05]$ anti- hyperglyceamic effect by ameliorating high blood sugar levels of alloxan-induced diabetic treated mice, while EF-II and EF-III showed non-significant[p $>0.05$ ] anti-hyperglyceamic activity for the reduction in blood sugar levels compared with the negative and positive control groups. The anti- diabetic potency of the crude leaf extracts and ethyl acetate fractions were in the order; $\mathrm{EC}>\mathrm{HC}>\mathrm{MC}>\mathrm{EF}-\mathrm{|}>\mathrm{EF}-\mathrm{II}>\mathrm{EF}-\mathrm{III}$. The results of phytochemical screening of the crude extracts and ethyl acetate bulked fractions showed the presence of tannins, flavonoids, saponins, alkaloids, terpenoids, glycosides, and steroids while reducing sugar was absent. The results from this study give credence to the use of Psidium guajava as an antidiabetic agent in the management of diabetes mellitus.

\section{Introduction}

Diabetes mellitus elucidates a metabolic disease characterized by abnormal hyperglycemia which alters the metabolism of lipids, carbohydrates, proteins arising from insulin deficiency or insensitivity of the target cells to insulin secreted in the body (Expert Committee on the Diagnosis and Treatment of Diabetes Mellitus, 2003). The prevalence of diabetes mellitus (DM) cases has been on the increase worldwide in recent years. The World Health Organization report released in 2000 estimated that over 171 million (2.8\%) people are living with diabetes mellitus in the global population, and this figure has been projected to increase to 366 million (4.4\%) by 2030 (Wild et al., 2004). Most especially, cases of type 2 diabetes mellitus (T2DM) have been increased in contrast to cases of type 1 (T1DM), an autoimmune disease that often occurs due to the destruction of insulin- producing beta cells of the pancreas, and results from a deficiency in insulin secretion (Kaplan, 1989). On the other hand, T2DM has become a more serious problem in developing countries because of the trend of urbanization and consequent lifestyle changes, perhaps most importantly exemplified by a shift to the western-style diet, which is high in fat (Matsuzawa, 1997). T2DM is mostly characterized by hyperglycaemia, insulin resistance (reduced insulin sensitivity), and obesity. Obesity is associated with not only T2DM but also hyperlipidemia and hypertension. The coexistence of these diseases is well known as metabolic syndrome, a high-risk factor for cardiovascular disease (Reaven, 1988). obesity results from a disequilibrium between energy intake and expenditure, and obesity is known to be a strong risk factor for Type-2 diabetes associated with insulin resistance (Bray et al., 2002).

\subsection{Origin, distribution, and morphology of Guava (Psidium guajava Linnaeus)}

Psidium guajava Linnaeus, widely known as guava is a member of the Myrtaceae family and a semideciduous tree that is native to tropical and subtropical countries with about 133 genera and more than 3,800 species (Haida et al., 2011). It is native and widely distributed in South and Central America. The Guava plant is now cultivated and naturalized throughout the tropics and subtropics in Africa, South Asia, Southeast Asia, the Caribbean, subtropical regions of North America, Hawaii, New Zealand, Australia, and Spain. It is well known in the islands for its edible fruit. However, the plant is cultivated today from the west coast of Africa to the Pacific region, including India and China, with varieties originally introduced over the past 300 years from the United States (Joseph and Mini, 2011). The two most common varieties of guava fruits are red (variety: Porifera) and white (variety: Porifera) (Haida et al., 2011). The Guava plant is a low evergreen tree that grows up to 6 to 25 feet tall, with wide-spreading branches and square downy twigs; it is widely grown for its fruit in the tropics. Generally, the guava plant has spread widely throughout the tropics because it thrives in a variety of soils, propagates easily, and bears fruit quickly. The guava berry is an important tropical fruit that is mostly consumed fresh. The fruit consists of a fleshy pericarp and a seed cavity with fleshy pulp and numerous small seeds of varying hardness depending on the cultivar (Jimenez-Escrig et al., 2001, Lapik et al., 2005; Lozoya et al., 2002). The flowers are white, incurved petals, 2 or 3 in the leaf axils; they are fragrant, with four to six petals and yellow anthers. The fruit is small, 3 to $6 \mathrm{~cm}$ long, pear-shaped, reddish-yellow, or creamy- white when ripe (Haida et al., 2011). It is commonly used as food and processed as juice and jam. The guava fruits are either eaten fresh or made into drinks, ice cream, and preserves. Guava fruit is still enjoyed as a sweet treat by indigenous peoples throughout the rainforest, and the leaves and bark of the guava tree have a long history of medicinal uses that are still employed today (Nwinyi et al., 2008). The tree is easily identified by its distinctive thin, smooth, copper-colored bark that flakes off, showing a greenish layer beneath. It is the hardest among tropical fruit trees and excels most of the other fruit crops in productivity and adaptability. Moreover, guava scores over other fruits in ascorbic acid, pectin, and other mineral contents. Guava cultivars, however, display a great diversity in tree size, bearing habit, and yield, as well as in fruit size, shape, quality, and ripening season (Joseph and Mini, 2011).

\subsection{Pharmacological Properties of Psidium guajava Linn.}

Different parts of the guava tree have been shown to possess various pharmacological activities due to their use in folk medicine for the treatment of different ailments. The potential pharmacologic activities of the extract from the fruit, leaf, bark, or roots include antioxidant, hepatoprotective, anti-allergy, antimicrobial, anti- genotoxic, anti-plasmodial, cytotoxic, antispasmodic, cardioactive, anti-cough, anti-diabetic, anti- inflammatory, and anti-conceptive activities in vitro and animal models (Gutiérrez et al., 2008). The extract of the whole plant of Psidium Guajava excluding roots was reported to possess antibacterial, antifungal, anti- viral, hypoglycaemic, and diuretic activities (Tripathi et al., 1981). In other studies, anti-diarrhoeal (Lutterodt, 1989), anti-pyretic (Olajide et al., 1999; Shinha et al., 2000), antihypertensive (Ayub et al., 2010) and bio-antimutagenic (Matsuo et al., 1994) properties of guava leaf extract have been demonstrated. Interestingly, guava leaves have also attracted attention as a folk remedy for diabetes not only in Japan and East Asia (Banu et al., 2012; Nien-yung and

Page 2/21 
Kuanghsiung, 2004) but also in Africa (Ojewole, 2005). Based on the need to maintain and promote good health and prevent lifestyle-associated diseases, the Japanese Ministry of Health, Labor and Welfare published "Foods for Specified Health Uses" (FOSHU), which are foods whose Claims of physiological effects on the human body have been officially approved and such foods were legally permitted to be used as dietary products for health preservation (Arai et al., 2008). Guava leaf tea, Bansoureicha that contains aqueous guava leaf extract was approved as FOSHU and recommended for individuals with pre- diabetes, the product has become widely accepted and commercially available in Japan (Ishida, 2001).

\subsubsection{Antioxidant properties of Guava}

Antioxidants are substances that can prevent or reduce the oxidative damage of biomolecules (lipids, proteins, and nucleic acids) by reactive oxygen free radicals such as superoxide, hydroxyl, peroxyl, alkoxyl, and nonradicals such as hydrogen peroxide, hypochlorous, etc. guava, compared with other fruits and vegetables, is also rich in antioxidants that help to reduce the incidence of degenerative diseases such as arthritis, arteriosclerosis, cancer, brain dysfunction, heart disease, and inflammation (Feskanich et al., 2000). Besides preventing or delaying oxidative damage of these essential biomolecules like lipids, proteins, and nucleic acids caused by reactive oxygen species, antioxidants were reported to retard aging (Feskanich et al., 2000; Gordon, 1996; Halliwell, 1996). They scavenge radicals by inhibiting the initiation and breaking of chain reactions, suppressing the formation of free radicals by binding to metal ions, reducing hydrogen peroxide, and quenching superoxide and singlet oxygen (Shi et al., 2001). Studies have shown that the most abundant antioxidants present in fruits are polyphenols and ascorbic acid, and polyphenols, which contain a significant amount of flavonoids which are mainly present in ester and glycoside forms (Fleuriet and Macheix, 2003). In the case of guava, free ellagic acid and glycosides of myricetin and apigenin are found to be present (Koo and Mohamed, 2001). Studies have shown that guava fruit and leaves possess antioxidant and free radical scavenging capacity (Chen et al., 2007).

\subsubsection{Anti-hyperlipidemic activity of Guava}

It has been reported that streptozotocin-induced diabetic rats treated with raw peel extract of P. guajava fruit for twenty-one days showed a significant decrease in serum triglycerides, total cholesterol, very-low-density lipoprotein (VLDL) cholesterol, low-density lipoprotein (LDL) cholesterol, and an increase in serum high- density lipoprotein (HDL) cholesterol (Rai et al.,2010). A long-term clinical trial that investigated the effects of the consecutive intake of guava for eight weeks on the parameters of hyperlipidemia, diabetes, and safety in twenty-three subjects with borderline or mild hyperlipidemia with or without type 2 diabetes mellitus showed much significant reduction in total serum cholesterol level, serum triglycerides level in subjects with hyper- triglyceamia and that of phospholipid in subjects with hyper-phospholipidemia. In addition, the extract significantly reduced blood glycosylated haemoglobin(HbA1c\%) and raised serum adiponectin levels in each subject with adiponectinemia and hyperglycemia conditions while levels of high-density lipoprotein cholesterol, non-esterified fatty acids (NEFAs), and lipid peroxide were not significantly reduced (Asano et al., 2007). In addition, research studies have shown that aqueous extract of Psidium guajava contains components of LDL-cholesterol that exhibit anti-glycation activity, suggesting its contribution to the prevention of neurodegenerative and cardiovascular diseases (Chen et al., 2010; Hsieh et al., 2005). Studies on humans have found that the consumption of guava for 12 weeks reduced blood pressure by $8 \%$, total cholesterol levels by $9 \%$, triacylglycerides by almost $8 \%$, and induced an $8 \%$ increase in the levels of HDLcholesterol. The authors attributed these effects to the fruit's high potassium and soluble fiber contents (Singh et al., 1993; Singh et al., 1992). Daily oral administration of red (pink) guava puree supplements showed a significant effect by reducing total cholesterol, low-density lipoprotein cholesterol and triglycerides levels, and resulted in an increase in high-density lipoprotein

cholesterol level in high fat diet induced obese rats (Norazmir and Ayub, 2010). Red (pink) guava is reported to have high crude fiber and mineral content, especially potassium, sodium, magnesium, phosphorus, zinc, and iron (Ayub et al., 2010).

\subsubsection{Hepatoprotective and Cardioprotective effects of Guava}

It has been reported that aqueous extract of lyophilized guava fruit peel exhibited a heptaprotective effect in diabetic test subject by maintaining a significant reduction in serum alanine aminotransferase (ALT), aspartate aminotransferase (AST), alkaline phosphatase (ALP), and creatinine levels in streptozotocininduced diabetic rats(Rai et al.,2010). In another study, it was noted that the oral administration of guava pulp and rat food supplemented with guava seeds significantly diminished the levels of AST and ALT enzymes in normal Wistar rats (Farinazzi-Machado et al., 2012). A study of aqueous extract of P. guajava showed a hepatoprotective activity in acute experimental liver injury induced by a combined mixture of carbon tetrachloride, paracetamol, and thioacetamide. The effects observed were compared with a known hepatoprotective agent, silymarin, and histological examination of the liver tissues that supported hepatoprotective activity (Roy et al., 2006). Other similar studies have also showed a cardioprotective effect of aqueous extract of P. guajava in myocardial ischemia-reperfusion injury in isolated rat hearts, which was primarily linked to its radical-scavenging action (Yamashiro et al., 2003).

\subsubsection{Anti-obese property of Guava}

A study has established that obesity results from an imbalance between energy intake and expenditure, and linked obesity as a predisposing risk factor to the development of Type-2 diabetes mellitus, which is often associated with insulin resistance (Bray et al., 2002). Studies have shown that there is an increasing prevalence of obesity among persons, which poses a global health challenge and hence, linked to some diseases. Obesity is the most common nutritional disorder affecting people in the developed world and it is considered a risk factor associated with the development of major human diseases, including cardiovascular disease, diabetes, and cancer. Significantly, daily consumption of fat-enriched diets often tends to promote obesity. In addition, increased intake of high caloric (energy and fat) food promotes body fat storage, greater body weight, and adiposity in humans (Bray et al., 2002); and animals (Estadella et al., 2004). Over-the-counter remedies like nutritional supplements are extremely popular, especially for weight reduction, obesity, and healthy vitality. Inhibition of digestion and absorption of dietary fats have been used as targets in obesity treatment (Weigle, 2003). Red guava purée intake has the 
beneficial effect of lowering body weight (Nzi et al., 2007; Norazmir and Ayub, 2010) and suppressing obesity in diet-induced obese rats (Norazmir and Ayub, 2010). Ram et al. (1992) reported that moderate feeding of pink guava purée caused changes in dietary fatty acids and carbohydrates.

\subsubsection{Anti-hypertensive activity of Guava}

A study on patients with essential hypertension showed that the guava extracts administered to subjects before meals in a randomized and single-blind fashion for twelve weeks led to a significant net decrease in blood pressure values and a significant increase in high-density lipoprotein cholesterol (HDL-C) after twelve weeks of Guava fruit substitution in hypertensive test subjects (Ram et al., 1992). Similar study has also demonstrated that red guava exhibits an antihypertensive property which is capable of reducing blood pressure (Ayub et al., 2010). In addition, it was reported that polyphenols prevented cardiac hypertrophy and the production of reactive oxygen species, as well as improved vascular function in antihypertensive experimental rat (Al-Awwadi et al., 2004). Red guava extract showed a significant lowering effect on systolic blood pressure of high-fat diet- induced obese rats (Norazmir and Ayub, 2010).

\subsubsection{Anti-diarrheal properties of guava}

It is evident that guava leaf extracts and fruit juice exhibited significant recovery rate among test subjects infected with infantile diarrhea in a clinical control experimental study. The study further reported that 62 infants treated with a separate oral administration of both leaf extracts and fruit juice had a significant recoverY rate of $87.1 \%$ within 3 days. It was concluded in the study that guava extract and fruit juice have a good anti- diarrheal effect against infantile rotaviral enteritis (Wei et al., 2000).

\subsubsection{Anti-mutagenic and anticancer properties of guava}

Few research studies have established anti-mutagenic and anticancer activities of P. guajava leaves. Notably, it has been reported that Psidium guajava pulp, peel, and seed extracts exert anticancer effects on both hematological and solid neoplasms, which were implicated as a result of antioxidant properties exhibited by the plant due to the presence of antioxidant compounds (Bomtempo et al., 2012).

\subsection{Aim of Study}

This study investigated the anti-hyperglycemia activities of n-hexane, methanol, ethyl acetate crude leaf extracts, and ethyl acetate bulked fractions of Psidium guajava in alloxan-induced diabetic mice.

\subsubsection{Objectives of the Study}

(i) To evaluate the phytochemical constituents of n-hexane, methanol, ethyl acetate crude leaf extracts, and ethyl acetate bulked fractions of Psidium guajava Linn.

(ii) To determine the mean lethal (acute) dose (LD50) of ethyl acetate crude leaf extract of Psidium guajava

Linn.

(iii) To assess antidiabetic activities of ethyl acetate, bulk fractions (EF-I, EF-II, and EF-III), n-hexane, ethyl acetate, and methanol crude leaf extracts of P. guajava to an approved reference anti-diabetic drug and negative control.

\section{Materials And Methods}

\subsection{Materials}

The test materials used in this research study include Wistar albino mice (animal), guava plant material, chemical reagents, and laboratory equipment.

\subsection{Animal}

Thirty-six (36) Wistar albino mice of body weight between 50-65g used for the study were purchased from the Animal House of the Department of Zoology, University of Nigeria, Nsukka Campus. The mice were fed with poultry starter feed, drinking water ad libitum, and acclimatized for seven (7) days. The mice were further divided into nine (9) groups consisting of four (4) mice per group.

\subsection{Drug/Chemical Reagents}

All chemicals and antidiabetic drugs (Glucophage) used in this study were based on the recommended standard and analytical grade. 
2.4 Instruments/Equipment

The equipment used for this study was domiciled at the Chemistry Department, Federal University of Agriculture, Markurdi and the Medical Biochemistry Department, University of Nigeria, Enugu State, Nigeria.

\subsection{Plant Material}

The plant leaves of Psidium guajava (Guava) used for this research study were obtained from the Botanical garden of the University of Nigeria, Nsukka Campus, Enugu State, Nigeria. The whole plant was identified by Dr. N. O Nweze, a renowned taxonomist in the Department of Plant Science and Biotechnology, University of Nigeria, Nsukka Campus, Enugu State, Nigeria.

\subsection{Experimental design}

Thirty-six (36) Wistar albino mice (50-65g) body weight were randomly divided into nine groups comprising four (4) mice per group (n=4/group). Group 1 was not induced with diabetes but received diluted dimethyl sulphoxide $(5 \mathrm{ml} / \mathrm{kg}$ ). Alloxan monohydrate (Merck, Germany) was dissolved in cold normal saline and administered intraperitoneally at a dose of $120 \mathrm{mg} / \mathrm{kg}$ per body weight to groups $2,3,4,5,6,7,8$, and 9 . The alloxanized groups were hyperglycemic when blood glucose levels rose to $\geq 120 \mathrm{mg} / \mathrm{dL}$. Group 3 received a standard antidiabetic drug (Glucophage, $5 \mathrm{mg} / \mathrm{kg}$ per body weight) while group 2 received dimethyl sulphoxide ( $5 \mathrm{ml} / \mathrm{kg}$ per body weight). The Group 4 mice received ethyl acetate bulked fraction I, EF-I (1-75) at a dose of $100 \mathrm{mg} / \mathrm{kg}$ per body weight. The same oral treatment was given to groups $5,6,7,8$, and 9 with ethyl acetate fractions; EF-II, EF-III, ethyl acetate crude extract, methanol extract, and hexane extract respectively at the same dose of $100 \mathrm{mg} / \mathrm{kg}$ as showed in Table 2.6.Oral administration of Glucophage, dimethyl sulphoxide, fractions and crude extracts of Psidium guajava leaves lasted for 14 days, during which the blood glucose concentrations of the mice were measured from the 1 st - 14 th day. The Psidium guajava leaf extracts were dissolved in fresh dimethyl sulphoxide and administered orally. The hypoglycemic effects of the crude extracts and ethyl acetate fractions were investigated on alloxan-induced diabetic mice.

Table 2.6: Administration of Crude Extracts and Ethyl acetate bulked fractions (EF-I, EF-II, and EF-III) of Psidium Guajava leaves in alloxan-induced diabetic mice.

\begin{tabular}{|c|c|}
\hline Group (4 mice per group) & Sample (Dosage) \\
\hline Group 1 (Normal control) & Dimethyl sulphoxide(DMSO) + distilled water $(5 \mathrm{ml} / \mathrm{kg}$ b.w) \\
\hline Group 2(negative control) & $(D M S O)+$ distilled water $(5 \mathrm{ml} / \mathrm{kg}$ b.w $)$ \\
\hline Group 3(diabetic treated/ positive control) & Glucophage (5mg/kg b.w) \\
\hline Group 4(diabetic treated mice) & Ethyl Acetate Fraction I(EF-I) $(100 \mathrm{mg} / \mathrm{kg}$ b.w) \\
\hline Group 5(diabetic treated mice) & Ethyl Acetate Fraction II(EF-II) (100mg/kg b.w) \\
\hline Group 6( diabetic treated mice) & Ethyl Acetate Fraction III(EF-III) $(100 \mathrm{mg} / \mathrm{kg} \mathrm{b.w)}$ \\
\hline Group 7(diabetic treated mice) & Ethyl Acetate Crude Extract (100mg/kg b.w) \\
\hline Group 8(diabetic treated mice) & Methanol Crude Extract (100mg/kg b.w) \\
\hline Group 9(diabetic treated mice) & N-hexane Crude Extract (100mg/kg b.w) \\
\hline
\end{tabular}

Ethical Clearance

The ethical clearance and permission to undertake this research was granted by the Research Ethics Committee, College of Medicine, University of Nigeria, Enugu State, Nigeria. The experiment was conducted, in accordance with the regulations of the Institutional Animal Research Ethics Committee, University of Nigeria, Enugu State, Nigeria.

\subsection{Preparation of Plant Material (P. guajava)}

The guava leaves were chopped and blended with a manual grinder into a fine powdery weighing three (3kg) kilograms.

\subsection{Extraction of Plant Material ((P. guajava)}

The leaf extraction was carried out by cold maceration (Akah et al., 2002; Akah and Okafor, 1992). Each one kilogram (1 kg) fine powder of dried Psidium guajava leaves was soaked in a separately labeled glass flask $(500 \mathrm{ml})$ containing $400 \mathrm{ml}$ of analytically graded n-hexane, ethyl acetate, and methanol reagent respectively. Each preparation was filtered through a grade 1 Whatman filter paper, and each filtrate was separately collected into a separate crucible before drying by evaporation under a steady air current for about 24 hours until a soft mass (extract) was obtained. Each crude extract obtained was weighed and 
recorded. The extracts were carefully air-dried to remove all traces of solvents under a thermal water bath. The percentage (\%) yields of $\mathrm{n}$-hexane, ethyl acetate, and methanol crude extracts were calculated, respectively.

2.10 Column Chromatographic Fractionation of Ethyl Acetate Crude Leaf Extract (Psidium guajava) Column glassware made up of a simple straight glass tube $60 \mathrm{~cm}$ long with a diameter size of $3.5 \mathrm{~cm}$ was used for column fractionation of ethyl acetate crude extract of Psidium guajava leaves. Firstly, the column glassware was rinsed with distilled water and later air-dried. A dried cotton wool plug was inserted into the bottom of the glass column just below the tap. The column chromatography was performed on silica gel (Machery Nagel, Germany) with a mesh pore size 70-230nm. The silica gel was packed into the glass column by the wet loading method before fractionating the ethyl acetate crude extract of Psidium guajava leaves to obtain fractionated bioactive constituents. The procedure for the gravity elution column chromatography was carried out by Harbone (1998) protocol as described below;

\section{Column Development}

The dry silica gel powder (Machery Nagel, Germany) with a mesh pore size of 70-230nm weighing $150 \mathrm{~g}$ was carefully packed into the glass column by the slurry packing(wet loading) method. The slurry silica gel was prepared by mixing dry silica gel powder and a solvent volume of $200 \mathrm{ml} n$-hexane (JHD $\AA$ ) in a glass beaker. The mixture was properly stirred for 10 minutes until the silica gel was properly preabsorbed. A ball of cotton wool was plugged just above the tap and $1.5 \mathrm{~mm}$ thick acid-treated sand $(\mathrm{BDH} \otimes)$ was added and allowed to settle onto the plugged cotton wool. The glass column was equilibrated with a few drops of $n$-hexane to achieve a marked level. The slurry was carefully poured into the column glassware and gently allowed to settle in the glass column. A vibrator was used to ensure that the column glass set-up was properly packed. The n-hexane solvent level was above the silica gel-packed column.

\section{Preparation of Plant Material for Column Fractionation}

The ethyl acetate crude leaf extract of Psidium guajava was placed into a clean beaker and properly stirred followed by the addition of a solvent mixture of dimethyl ether and ethyl acetate (2:1) to preabsorb the mixture, and air-dried. A fine powder of ethyl acetate crude extract of P. guajava leaves was obtained after air drying. The fine powder of ethyl acetate crude extract of Psidium guajava leaves weighing $1.5 \mathrm{~g}$ was added onto a $1.5 \mathrm{~mm}$ thick acid-treated sand layer (BDH, England) just above the wet silica gel in the column.

\section{Solvent System}

The column fractionation was carried out using different solvent systems (mixtures) using pure analytical graded reagents in sequence and polarity strength.The volume ratios of $n$-hexane: ethyl acetate were used in the fractionation process with varying percentage volume ratios (100\%:0\% - 50\%:50\%). At the beginning of column fractionation, a solvent volume ratio of $500 \mathrm{ml}$ volume of $\mathrm{n}$-hexane $(100 \%)$ : ethyl acetate ( $0 \%)$ was used to elute nonpolar compounds. The sequence and polarity to volume ratios of the solvents were considered to avoid column cracking and achieve efficient separation. At the end stage of the fractionation, the column was thoroughly washed with $500 \mathrm{ml}$ of $99.9 \%$ methanol to obtain the methanol fraction separately. The solvent system (mixture) was continuously added and a gradual flow rate of 10 drops per minute was obtained.

\section{Fraction Collection}

Serial labeled glass vials $(5 \mathrm{ml})$ were used for collecting solvent fractions (eluents). The collection of fractions was achieved after a successive elution to obtain a total number of two hundred and fifty (250) vial fractions. The solvent vial fractions were kept uncovered to air-dry for 24 hours after collection. The solute deposited in each vial was redissolved with a $5 \mathrm{ml}$ ethyl acetate solution (JHD®, China). The vial fractions were grouped into three main bulk fractions; EF-I, EF-II, and EF-III according to the retention factor (Rf) values of the thin layer chromatography fingerprints (TLC) plates (Chromatogram).

\subsection{Thin Layer Chromatography (TLC)}

Thin-layer chromatography (TLC) is one of the laboratory techniques applied in organic research laboratories. It is used to achieve a quick separation of organic compounds and to ascertain the level of purity of a given mixture. TLC also helps to detect and analyze organic one or more compounds by comparing with known samples in terms of its purity with identified samples as well as monitoring the progress of separation during the extraction or purification process. The TLC comprises of a small glass or plastic plate coated with a thin layer of a dry solid silica gel or alumina gel, which serves as the most common stationary phase. Mobile phase could be an organic solvent or solvent mixture. The sample mixture is spotted near the bottom of the plate as a small, and then placed in a developing chamber containing a little volume of solvent (mobile phase). The solvent travels up the plate and carries the sample mixture along with it through the capillary action. As a result of the solubility of various components of the mixture in the mobile phase, the strength of their adsorption on the stationary phase and each component in the mixture moves at a different rate. As the solvent moves near the top of the plate (solvent front). It is allowed to evaporate, leaving behind the components of the mixture at various distances from the point of origin (Dhont, 1980). The ratio of the distance traveled by a compound to the distance traveled by the solvent is the Rf value (retention factor). This value is characteristic of the compound, the solvent, and the stationary phase (Dhont, 1980). The retention factor, $\mathrm{Rf}=$ distance traveled by sample/ distance traveled by solvent.

Procedure: 
Thin-layer chromatography (TLC) was performed on a silica gel precoated plate (GF254, Merck, UK). A solvent volume ratio of n-hexane to ethyl acetate $(5 \mathrm{ml}: 5 \mathrm{ml})$ was used as the mobile phase for each fraction; EF- I, EF-II, and EF-III. The plates were sprayed with a mixture of $20 \%$ sulphuric acid dissolved in methanol and then heated to about $120^{\circ} \mathrm{C}$ for 3 minutes to visualize spots. This is suitable for the detection of most polar compounds such as carbohydrates, etc. A total of two hundred and fifty (250) eluted fractions were further bulked into three main groups of ethyl acetate fractions based on the separation pattern of the constituent compounds (Rf values) and labeled EF-I (1-75), EF-II(76-150) and EF-III(151-250) accordingly.

\section{Results}

3.1 Actual and Percentage Yield of Plant Extracts and Column Fractions

The plant extraction yielded $1.5 \mathrm{~g}(21 \% \mathrm{w} / \mathrm{w}) \mathrm{n}$-hexane crude extract, $3.0 \mathrm{~g}(42 \% \mathrm{w} / \mathrm{w})$ ethyl acetate crude extract, and $2.51 \mathrm{~g}(35 \% \mathrm{w} / \mathrm{w}) \mathrm{methanol} \mathrm{crude}$ extract of Psidium guajava Linn leave

Table 3.1(a): Yield of Psidium guajava Crude Leaf Extracts

\begin{tabular}{|llll|}
\hline S/No & Type of Extract & Amount of Extract (gm) & \% Yield \\
\hline 1. & N-hexane & 1.5 & 21 \\
\hline 2. & Ethyl acetate & 3.0 & 42 \\
\hline 3. & Methanol & 2.51 & 35 \\
\hline
\end{tabular}

Table 3.1(b): Bulking of Column Fractions of P. guajava Ethyl Acetate Crude Leaf Extracts

\begin{tabular}{|lll|}
\hline S/No & Ethyl acetate Bulked Fractions & Range of Combined Fractions \\
\hline 1. & Bulk Fraction I (EF-I) & $1-75$ \\
\hline 2. & Bulk Fraction II (EF-II) & $76-150$ \\
\hline 3. & Bulk Fraction III (EF-III) & $151-250$ \\
\hline
\end{tabular}

The column fractionation yielded 250 column fractions which were bulked together into three main bulked fractions (EF-I, EF-II, and EF-III), respectively.

Table 3.1 (c): Retention Factor Values (Rf) of Ethyl Acetate Fractions of Psidium guajava Leaves.

\begin{tabular}{|llc|}
\hline S/N & Bulk Fractions & Retention Factor(Rf) Values \\
\hline 1 & Bulk Fraction I(1-75) & 0.33 \\
\hline 2 & Bulk Fraction II(76-150) & 0.19 \\
3 & Bulk Fraction III(151-250) & 0.23 \\
\hline
\end{tabular}

Table 3.1(d): Qualitative Phytochemical Screening of Ethyl Acetate Fractions of Psidium guajava Leaves. 


\begin{tabular}{|c|c|c|c|}
\hline \multirow[t]{3}{*}{ PYTOCHEMICAL CONSISTUENTS } & \multicolumn{3}{|l|}{ ABUNDANCE } \\
\hline & ETHYL ACETATE & ETHYL ACETATE & ETHYL ACETATE BULK FRACTION (EF-III) \\
\hline & BULK FRACTION (EF-I) & BULK FRACTION (EF-II) & \\
\hline Reducing Sugar & - & - & - \\
\hline Tannins & + & + & + \\
\hline Steroids & ++ & + & + \\
\hline Flavonoids & ++ & + & + \\
\hline Saponins & ++ & + & - \\
\hline Alkaloids & ++ & + & + \\
\hline Terpenoids & ++ & + & + \\
\hline Glycosides & - & - & - \\
\hline
\end{tabular}

*Interpretation: -Absence, + Trace, ++Moderate, +++ Abundant

Table 3.1(e): Qualitative Phytochemical Screening of Ethyl Acetate, Methanol, and n-Hexane Crude Extracts of Psidium guajava Leaves.

\begin{tabular}{|c|c|c|c|c|c|}
\hline \multirow{2}{*}{$\begin{array}{l}\text { PYTOCHEMICAL } \\
\text { CONSISTUENTS }\end{array}$} & \multicolumn{3}{|c|}{ ABUNDANCE } & \multirow[b]{2}{*}{$\begin{array}{l}\text { METHANOL CRUDE } \\
\text { (MC) }\end{array}$} & \multirow[b]{2}{*}{ EXTRACT } \\
\hline & $\begin{array}{l}\text { N-HEXANE CRUDE EXTRACT } \\
(\mathrm{HC})\end{array}$ & $\begin{array}{l}\text { ETHYLACETATE CRUDE } \\
(\mathrm{EC})\end{array}$ & EXTRACT & & \\
\hline Reducing Sugar & - & - & & - & \\
\hline Tannins & ++ & ++ & & +++ & \\
\hline Steroids & ++ & +++ & & ++ & \\
\hline Flavonoids & + & +++ & & ++ & \\
\hline Saponins & + & + & & + & \\
\hline Alkaloids & + & ++ & & + & \\
\hline Terpenoids & + & + & & ++ & \\
\hline Glycosides & + & - & & - & \\
\hline
\end{tabular}

*Interpretation: -Absence, + Trace, ++Moderate, +++ Abundant

3.2 Determination of Mean Acute (Lethal) Toxic Dose (LD50)

The mean acute toxic dose was determined in two phases I and II at different dosages of ethyl acetate crude leaf extract of Psidium guajava. The acute toxicity study was determined in mice using the method of Lorke (1983). The tests involved two phases. The first phase was used to determine the toxic range. The three groups 1, 2, and 3 comprising of three (3) mice was separately administered 10mg/kg b.w, $100 \mathrm{mg} / \mathrm{kg} \mathrm{b.w,} \mathrm{and} 1000 \mathrm{mg} / \mathrm{kg} \mathrm{b.w} \mathrm{doses} \mathrm{of}$ ethyl acetate crude leaf extract solubilized in $5 \%(\mathrm{v} / \mathrm{v})$ dimethyl sulphoxide. The treated mice were observed after $24 \mathrm{hrs}$ for any lethal signs, abnormal behaviour, and death. There was no lethal signs and death recorded. In the second phase of the toxicity study, each group was separately administered with different doses of 1500,2000 , and $5000 \mathrm{mg} / \mathrm{kg}$ per body weight of ethyl acetate crude leaf extract, respectively. The treated mice were observed after $24 \mathrm{hrs}$ for lethality or signs of acute intoxication. The acute toxic dose (LD50) was calculated. The result obtained is shown below: 


\begin{tabular}{|llllll|}
\hline Phase & Groups of Mice & Dosage $(\mathbf{m g} / \mathbf{k g ~ b . w . )}$ & Mortality & Behavioural & Changes \\
& (3 mice per group) & & & \\
\hline Phase I & Group 1 & 10 & $0 / 3$ & Nil \\
\cline { 2 - 5 } & Group 2 & 100 & $0 / 3$ & Nil \\
\cline { 2 - 5 } Phase II & Group 1 & 1000 & $0 / 3$ & Nil \\
\cline { 2 - 5 } & Group 2 & 1500 & $1 / 3$ & yes \\
& Group 3 & 2000 & $2 / 3$ & yes \\
\cline { 2 - 5 } & 5000 & $2 / 3$ & yes \\
\hline
\end{tabular}

Figure 3.5.1(A and B) showed the results of percentage mean blood glucose(Mean \pm SEM) reduction of treatment groups on the first(1st) and fifth(5th) day of oral treatment. The positive control(group 3) mice were treated with Glucophage at a dose of $5 \mathrm{mg} / \mathrm{kg} \mathrm{b.w}$, while groups 4, 5, and 6 were treated with ethyl acetate fractions (EF I), (EF II) and (EF III) at a dose of $100 \mathrm{mg} / \mathrm{kg}$ b.w and group 7, 8 and 9 treated with ethyl acetate, methanol and n-hexane crude extracts of P. guajava leaves at a dose of $100 \mathrm{mg} / \mathrm{kg} / \mathrm{b} . \mathrm{w}$ respectively. The oral treatment of alloxan-induced diabetic mice with crude and partially purified chromatographic fractions on Day 1, group 8 mice treated with methanol crude(MC, $100 \mathrm{mg} / \mathrm{kg} \mathrm{b.w})$ leaf extract of P. guajava showed the highest percentage blood glucose reduction with a mean (Mean \pm SEM) (45\%), followed by n-hexane, HC(42\%) and ethyl acetate crude extract (40\%), EF I (39\%) while EF II(18\%) and $\mathrm{EF} \mathrm{III}(10 \%)$ had least percentage blood glucose reduction. A statistical comparison of the anti-hyperglycemia effect between all treatment groups and positive controls using a One-way ANOVA (Dunnett's multiple) showed that each bar(Mean \pm SEM) was not significantly different from the positive control group(18\% mean percentage blood glucose reduction). This implies that the groups treated with EF I, EF II, EF III, ethyl acetate, methanol, and n-hexane crude extract of P. guajava leaves had a significant anti-hyperglyceamic effect with a percentage reduction in high blood glucose level compared with the standard reference drug (Glucophage, $5 \mathrm{mg} / \mathrm{kg}$ b.w) in the order of $\mathrm{MC}>\mathrm{HC}>\mathrm{EC}>\mathrm{EF}-\mathrm{I}>\mathrm{EF}-\mathrm{II}$ while the EF-III had a least anti-hyperglyceamic effect with percentage glucose reduction. On the second(2nd) day of oral treatment of alloxan-induced diabetic mice with crude and partially purified chromatographic column fractions, group 7 mice treated with ethyl acetate crude $100 \mathrm{mg} / \mathrm{kg} \mathrm{b.w)} \mathrm{leaf} \mathrm{extract} \mathrm{of} \mathrm{P.} \mathrm{guajava} \mathrm{showed} \mathrm{the} \mathrm{highest} \mathrm{percentage} \mathrm{blood} \mathrm{glucose} \mathrm{reduction} \mathrm{with} \mathrm{a} \mathrm{mean}$ (Mean \pm SEM) (43\%), followed by methanol, MC (40\%), and n-hexane extract(39\%), EF I (31\%) while EF II(15\%) and EF III(13\%) had least percentage blood glucose reduction. A statistical comparison between all treatment groups and positive controls(group 3) using Dunnett's multiple One way ANOVA showed that each bar (Mean \pm SEM) was not significantly different from the positive control group( $40 \%$ mean percentage blood glucose reduction). This implies that the groups treated with EA fraction I, EA fraction II, EA fraction III, ethyl acetate, methanol, and n- hexane crude extract of P. guajava leaves had a significant anti-hyperglyceamic effect compared with the standard reference drug (Glucophage) administered at a dose of $5 \mathrm{mg} / \mathrm{kg} \mathrm{b.w} \mathrm{in} \mathrm{the} \mathrm{order} \mathrm{of} \mathrm{EC>MC>HC>EF-I}$ >EF-II while the EF-III had least percentage blood glucose reduction.

On the eighth $\left(8^{\text {th }}\right)$ day of oral treatment of alloxan- induced diabetic mice with crude and partially purified chromatographic fractions. Group 7 mice treated with ethyl acetate(EC, $100 \mathrm{mg} / \mathrm{kg}$ b.w) crude leaf extract of $P$. guajava showed the highest percentage mean blood glucose reduction with a mean(Mean \pm SEM) (43\%), followed by methanol, MC(39\%) and n-hexane extract, HC (30\%), EF I (25\%), EF III(5\%) while EF II showed least mean percentage blood glucose reduction. A statistical comparison of the anti-hyperglycemia effect of all treatment groups and positive controls using One-way ANOVA (Dunnett's multiple) showed that each bar (Mean \pm SEM) was not significantly different from the positive control group(40\%mean percentage blood glucose reduction). This implies that the groups treated with EA fraction I, EA fraction II, ethyl acetate, methanol, and n-hexane crude leaf extract of $P$.guajava had a significant antihyperglycemia effect compared with the standard reference drug(Glucophage administered at a dose of $5 \mathrm{mg} / \mathrm{kg}$ b.w) in the order of $\mathrm{EC}>\mathrm{MC}>\mathrm{HC}>\mathrm{EF}-\mathrm{I}>\mathrm{EF}$ III>EF-II, even though EA fraction II(EF-II) had least percentage blood glucose reduction. On the eleventh ( $\left.11^{\text {th }}\right)$ day of oral treatment of alloxan-induced diabetic mice with crude and partially purified chromatographic fractions. The group 7 mice treated with ethyl acetate crude (100mg/kg b.w) leaf extract of P. guajava showed the highest percentage blood glucose reduction with a mean (Mean \pm SEM) (40\%), followed by methanol(38\%) and n-hexane extract(30\%), EF I (25\%) while EF II(18\%) had least percentage blood glucose reduction and EF III had $-5 \%$ with no significant mean blood glucose reduction. A statistical comparison of the anti-hyperglycemia effect between all treatment groups and positive controls using One-way ANOVA (Dunnett's multiple analysis) showed that each bar (Mean \pm SEM) was not significantly different from the positive control group(42\% mean percentage blood glucose reduction). This implies that all treatment groups treated with EF I, EF II, EF III, ethyl acetate, methanol and n-hexane crude extract of P.guajava leaves at a dose of $100 \mathrm{mg} / \mathrm{kg}$ b.w had a significant antihyperglycemia effect compared with the standard reference drug (Glucophage) administered at a dose of $5 \mathrm{mg} / \mathrm{kg}$ b.w in the order of EC>MC>HC>EF-I >EF-II $>$ EF-III.

Figure 3.5.3 showed the result of percentage blood glucose reduction (Mean \pm SEM) for the treatment groups on the fourteenth (14th) day of oral treatment of alloxan-induced diabetic mice(group 3) with the reference drug(Glucophage) at a dose of $5 \mathrm{mg} / \mathrm{kg}$ b.w. Groups 7, 8, and 9 were treated with ethyl acetate, methanol, and n-hexane at a particular dose of $100 \mathrm{mg} / \mathrm{kg}$ b.w, and groups 4, 5, and 6 were treated with ethyl acetate fractions(EF-I, EF- II \& EF-III) at a $100 \mathrm{mg} / \mathrm{kg}$ b.w of $P$. guajava leaves respectively.

On the Fourteenth $\left(14^{\text {th }}\right)$ day of oral treatment of alloxan-induced diabetic mice with crude extracts and partially purified ethyl acetate fractions. The group 7 mice treated with ethyl acetate crude $(100 \mathrm{mg} / \mathrm{kg}$ b.w) leaf extract of $P$. guajava had the highest percentage mean blood glucose with $43 \%($ Mean \pm SEM), followed by methanol, MC(35\%), and n-hexane extract, HC (30\%), EF I (20\%) while EF II(18\%) while EF 
III(4\%) had least percentage blood glucose reduction. A statistical comparison of the anti-hyperglycemia effect of all treatment groups and positive controls (group 3) using a one way ANOVA (Dunnett's multiple) showed that each bar (Mean \pm SEM) was not significantly different from the positive control group (59\%) mean percentage blood glucose reduction). This implies that each group treated with EF I, EF II, EF III, ethyl acetate, methanol, and nhexane crude extract of P.guajava leaves had much significant anti-hyperglyceamic effect compared with the standard reference drug (Glucophage) administered at a dose of $5 \mathrm{mg} / \mathrm{kg}$ b.w in the order of EC>MC>HC>EF-I >EF-II while the EF-III had least percentage blood glucose reduction.

\section{Discussion}

Diabetes mellitus is a metabolic condition categorized with several etiologies and chronic hyperglycemia

caused by disturbances of carbohydrate, fat, and protein metabolism resulting from defects in insulin secretion, insulin action, or both(Wild et al., 2004). Diabetes mellitus is caused by the abnormality of carbohydrate

metabolism, which is linked to low blood insulin levels or insensitivity of target organs to insulin (Lincy et al. 2016). It has been considered an incurable metabolic disorder affecting about $2.8 \%$ of the global population. Despite considerable progress in the treatment of diabetes by oral hypoglycemic agents, the search for newer drugs continues because the existing synthetic drugs have several limitations (Arumugam et al., 2013).

Alloxan treatment is a method widely used to induce hyperglycemia conditions (diabetes mellitus) in animals using alloxan, a glucose analog which is selectively toxic to pancreatic beta cells due to its accumulation in beta cells. The mechanism of action of alloxan is enhanced by the presence of cysteine amino acid residue which contains two - SH groups that form a disulfide bond thereby inactivating enzyme.

As a result of alloxan reduction, diuric acid is then re-oxidized back to alloxan, hence establishing a redox cycle for the generation of reactive oxygen species and superoxide radicals (Wild et al., 2004). The cytotoxic action of alloxan is mediated mainly by these reactive oxygen species (ROS). Reactive oxygen species cause the fragmentation of the DNA of pancreatic islets, which occurs in beta cells exposed to alloxan monohydrate (Lincy et al., 2016).

The preliminary acute toxicity (LD50) study of ethyl acetate crude leaf extract of Psidium guajava was carried out in different phases to establish the lethal ora The results showed that more than $500 \mathrm{mg}$ of ethyl acetate crude extract of the plant leaves was safe for consumption as a decoction.

This study further evaluated the anti-hyperglycemic effects of methanol, ethyl acetate, and n-hexane crude extracts and ethyl acetate bulked fractions of Psidium guajava Linn leaves in alloxan-induced diabetic mice and the results showed a significant anti-

hyperglyceamic effect in reduction of high blood glucose levels in test groups treated with a dose of $100 \mathrm{mg} / \mathrm{kg}$ of each crude leaf extract of $P$. guajava as compared with negative and positive controls.

However, the results of anti-hyperglycemic effect of ethyl acetate crude extract (EC) of $P$. guajava on alloxan- induced diabetic mice(group 7) exhibited much significant $[P<0.001, P<0.01 ; P<0.05]$ blood glucose reduction throughout the oral treatment which lasted on the twelfth(12th) day of oral treatment, while alloxan-induced diabetic mice(group 9) treated $\mathrm{n}$-hexane crude extract ( $\mathrm{HC}, 100 \mathrm{mg} / \mathrm{kg} \mathrm{b.w})$ of Psidium guajava leaves showed a significant $[\mathrm{P}<0.001, \mathrm{P}<0.01$; $\mathrm{P}<0.05]$ anti-hyperglyceamic control which lasted on 7th day of oral treatment compared with negative control(group 2). The alloxan-induced diabetic mice (group 8 ) treated with $100 \mathrm{mg} / \mathrm{kg}$ of methanol extract of $P$. guajava leaves also showed significant $[P<0.001, P<0.01 ; P<0.05]$ anti-hyperglyceamic control which lasted on the fifth(5th) day of oral administration compared with negative control(group 2).

The group 4 mice treated with ethyl acetate fraction I(EF-I) $(100 \mathrm{mg} / \mathrm{kg}$ b.w) showed a significant $[\mathrm{P}<0.05]$ anti-hyperglycemia effect compared with the negative control(group 2) that lasted on the second $\left(2^{\text {nd }}\right)$ day of oral treatment, while EF-Il showed invariably a least significant glucose control in the test group as compared with control groups. Ef-iii exhibited a nonsignificant [P>0.05] hypoglyceamic effect as compared with the negative controls (group 2), despite a gradual decline in high blood glucose levels throughout the period of oral administration. However, the pattern of response or decrease in random blood glucose concentration of diabetic treated groups differed significantly over the period (days) of oral administration of each crude extract and ethyl acetate fractions respectively.

The high anti-hyperglycemic effect observed among different treatment groups with crude extracts and ethyl acetate bulked fraction I(EF-

I) administered at a specific dose of $100 \mathrm{mg} / \mathrm{kg}$ b.w can be attributed to the presence of rich antidiabetic bioactive compounds present in the crude extracts and bulked ethyl acetate fraction I (EF-I) of Psidium guajava leaves, since the qualitative phytochemical screening of crude leaf extracts, and ethyl acetate bulked fraction I(EF I) showed a significant presence of alkaloids, flavonoids, steroids, and terpenoids

which have been identified. In general, there is increasing biological knowledge on the specific modes of action of medicinal plants in the treatment of diabetes, but most of the plants have been found to contain substances like glycosides, alkaloids, terpenoids, and flavonoids that are frequently implicated as having an antidiabetic effect (Lincy et al., 2016). However, the methanol crude extract showed a moderate significant decrease in high blood glucose levels in treated mice (group 8), while ethyl acetate fractions II and III showed a nonsignificant decrease in blood glucose level of alloxaninduced diabetic groups 5 and 6 respectively when compared with diabetic untreated control (group 2) due to the little or trace amount of these bioactive compounds. There are possible explanations for these findings, despite that there is no clear explanation of the in vitro mechanism of action of Psidium guajava crude extracts and ethyl acetate bulked fraction as an antidiabetic agent. It may be hypothesized that the major phytochemical constituent(s) of the crude extract and ethyl acetate bulked fractions may have delayed or reduced glucose absorption from the gastrointestinal tract into the circulatory system, through inhibition of carbohydrate digestion, or inhibition of Na+-glucose co-transporters and facilitated glucose transporters on the luminal (mucosal) side of the absorptive cells of intestinal epithelial cells, or inhibition of $\mathrm{Na}^{+} \mathrm{K}^{+}$- ATPase on the serosa side of intestinal epithelial cells. Moreover, the crude extracts of Psidium guajava leaves may have triggered the recovery of partially destroyed $\beta$-cells or possibly Psidium guajava leaf crude extracts of $n$-hexane, ethyl acetate, and methanol and ethyl acetate bulked fraction I, EF-I(1-75) may have initiated cell proliferation after induction of diabetes with alloxan monohydrate $(120 \mathrm{mg} / \mathrm{kg}$, i.p) in test mice. There was a nonsignificant reduction in blood glucose levels of alloxan-induced diabetic mice (groups 5 and 6$)$ treated with ethyl

Page 10/21 
acetate bulk fractions, EF-II and EF-III compared with negative and positive controls, despite the presence of trace amounts of these phytochemical constituents. The nonsignificant anti- hyperglyceamic effect showed by ethyl acetate bulk fractions, EF-II and EF-III were due to the loss of potent antibioactive compounds during the fractionation process and these bioactive compounds have been implicated to elicit pharmacologic activity or synergistic that enhances anti-diabetic activity of fractions.

\section{Conclusion}

This study has shown that ethyl acetate crude leaf extract of Psidium guajava Linn exhibited a very high potent antidiabetic effect followed by methanol, $\mathrm{n}$ hexane crude leaf extract and ethyl acetate bulk fraction I(EF-I) by lowering the high blood glucose level in alloxan-induced diabetic treated mice compared with diabetic untreated(negative control) in the order of $E C>M C>H C>E F-I>E F-I \mid>E F>I I I$. The result findings showed that the ethyl acetate bulked fractions, EFII and EF-III exhibited a nonsignificant anti-hyperglycemia effect compared with negative control mice (group 2), and despite the gradual decrease in high blood glucose concentration. In addition, a comparison of a percentage mean glucose reduction (Mean \pm SEM) of all diabetic treated groups with EF-I and all crude extracts administered at a dose of $100 \mathrm{mg} / \mathrm{kg}$ b.w which showed a non-

significant difference from the positive control mice(group 3) treated with Glucophage ( $5 \mathrm{mg} / \mathrm{kg} \mathrm{b.w)}$ ), a standard anti-diabetic drug.The phytochemical screening of methanol, ethyl acetate, n-hexane, crude leaf extract, and ethyl acetate bulk fractions of Psidium guajava showed a rich abundance of alkaloids, steroids, flavonoids, tannins, and saponins and absence of glycosides and reducing sugar were observed in EF-I, EF-II, EF-III, EC, HC, and MC. The LD50 of ethyl acetate crude leaf extract of Psidium guajava was determined within the range of $1200-1500 \mathrm{mg} / \mathrm{kg} /$ body weight, thus suggesting a wide safety margin for use in animal model experiments. In conclusion, the resulting findings from this study have given credence to the use of $P$ sidium guajava leaves as a traditional remedy for the treatment and management of diabetes mellitus.

\section{Recommendation}

In future studies, it is recommended that emphasis should be made towards the use of advanced chromatographic techniques for both fractionation and purification of crude extracts of Psidium guajava leaves. The use of advanced chromatographic techniques like High-Performance Liquid Chromatography (HPLC), Gas Chromatography Mass Spectrometry (GC-MS) and molecular spectroscopy should be used to further isolate, identify and characterize potent antidiabetic drug compound(s) in the purified fraction that may be linked to the anti-diabetic property of Psidium guajava. It is also necessary to carry out in vivo and in vitro antidiabetic studies of antihyperglyceamic activity of ethyl acetate fractions of Psidium guajava leaves with varying doses $(200 \mathrm{mg} / \mathrm{kg} \mathrm{b.W,400} \mathrm{mg} / \mathrm{kg} \mathrm{b.w} \mathrm{and} 600 \mathrm{mg} / \mathrm{kg} \mathrm{b.w)} \mathrm{on} \mathrm{a}$ specific cultured cell line and alloxan-induced diabetic mice over a prolonged duration, to assess the dose-dependent anti-hyperglycemic effect of each fraction. The medicinal value of Psidium guajava plant should be given more attention towards developing new antidiabetic drugs and other therapeutic drug researches.

\section{Declarations}

\subsection{AUTHORS' CONTRIBUTIONS}

This work was extensively conducted by Mr. Eze Uchenna Nwabunwanne under the supervision of Associate Prof. Anthonius A. Eze from the Department of Medical Biochemistry, Faculty of Basic Medical Sciences, University of Nigeria,Enugu, Nigeria. The Author conducted the literature search, experimental design and in vivo bioassay, statistical analyses, proof-reading, and editing of the manuscript. All co-authors contributed to the success of this research by sharing knowledge, research experience, and financial resources.

8.0 CONFLICTS OF INTEREST: We declare that there are neither conflicts of interests nor funding sponsors in executing this research paper.

\section{References}

Akah P.A., Okoli, C. O. and Nwafor, S.V.,(2002).Phytotherapy in the management of diabetes mellitus. Journal of Natural Remedies.2:1-10.

Akah, P.A. and Okafor, C.L.,(1992).Blood Sugar lowering effect of Vernonia amygdalina in an experimental rabbit model. Phytotherapy Research, 6: 171-173

Al-Awwadi, N.A., Bornet, A. and Azay, J.(2004). Red wine polyphenols alone or in association with ethanol prevent hypertension, cardiac hypertrophy, and production of reactive oxygen species in the insulin- resistant fructose-fed rat. Journal of Agriculture and Food Chemistry, 52: 5593-5597.

American Diabetes Association (2012). Diagnosis and classification of diabetes mellitus. Diabetes Care, 35(1): 64-71.

American Diabetes Association(2010).Diagnosis and classification of diabetes mellitus. Diabetes Care, 33(1): 62-69.

Arai, S., Yasuoka, A. and Abe, K.(2008). Functional food science and food for specified health use policy in Japan: State of the art. Current Opinion in Lipidology, 19:69-73.

Arumugam, G., Manjula, P. and Paari, N.(2013). A review: Antidiabetic medicinal plants used for diabetes mellitus. Journal of Acute Disease. 196200(13):60126-2.

Ayub, M.Y., Norazmir, M.N., Mamot, S., Jeeven, K., and Hadijah H. (2010).Anti-hypertensive effect of pink guava(Psidium guajava) puree on spontaneous hypertensive rats. International Food Research Journal, 17:89-96. 
Banu, M. S., Sujatha, K., Beena, W. S. and Divya, N.(2012). Anti- hyperglycemia and antioxidant potentials of Psidium guajava leaf extract and its isolated fraction in alloxan-induced diabetic rats. Research Journal of Pharmacy and Technology, 5(4):541-546.

Bennett, W. L., Maruthur, N. M., Singh, S., Segal, J. B., Wilson, L. M., Chatterjee, R., Marinopoulos, S. S., Puhan, M. A., Ranasinghe, P., Block, L., Nicholson, W. K., Hutfless, S. Bass, E. B. and Bolen, S.(2011).Comparative effectiveness and safety of medications for type 2 diabetes: An update including new drugs and 2drug combinations. Annals of Internal Medicine, 154(9): 602-613.

Bluestone, J.A., Herold, K., and Eisenbarth, G.(2010).Genetics, pathogenesis and clinical interventions in type 1 diabetes. Nature, 464:1293-1300.

Bontempo, P., Doto, A., Miceli, M., Mita, L., Benedetti, R., Nebbioso, A., Veglione, M. and Rigano, D.(2012). Psidium guajava L. anti-neoplastic effects: induction of apoptosis, cell differentiation, and Cell Proliferation, Nature, 45(1): 22-31.

Borch-Johnsen, K., Joner, G. and Mandrup-Poulsen, T.(1984). Relation between breast-feeding and incidence rates of insulin-dependent diabetes mellitus: A hypothesis. Lancet, 2 (8411): 1083-1086.

Bray, G.A., Lovejoy, J.C., Smith, S.R., DeLany, J.P., Lefevre, M. and Hwang, D.(2002).The influence of different fats and fatty acids on obesity, insulin resistance, and inflammation. Journal of Nutrition, 132(9): 2488-2491.

Brunton, L.L., Lazo, J.S. and Parker, K.L.(2006). Goodman and Gilman's: The pharmacological Basics of therapeutics, 11th edition, Washington, DC: Goodman and Gilman's Publishers Inc, p.p 60-70.

Carter, P., Gray, L.J., Troughton, J., Khunti, K. and Javies, M.D.(2007). Diabetes mellitus: A guide to patient care. Philadelphia: Lippincott Williams and Wilkins Publishers. p.p 201-210.

Chatzigeorgiou, A., Harokopos, V., Mylona-Karagianni, C. Tsouvalas, E. Aidinis, V. and Kamper, E.F.(2010).The pattern of inflammatory/antiinflammatory cytokines and chemokines in type 1 diabetic patients over time. Annals of Medicine, 42(6): 426-38.

Chen, K.C., Chuang, C.M., Lin, L.Y., Chiu, W.T., Wang, H.E., Hsieh, C.L., Tsai, T. and Peng, R.Y.(2010).The polyphenolics in the aqueous extract of Psidium guajava kinetically reveal an inhibition model of LDL glycation. Pharmaceutical Biology, 48(1): $23-31$.

Cheng, J.T.and Yang, R.S.(1983).Hypoglycaemic effect of guava juice in mice and human subjects.American Journal of Chinese Medicine, 11:74-76.

Cho, E.J., Yokozanawa, T. Y., Rhyu, D.Y., Kim, S.C., Shibahara, N. and Park, J.C.(2003). Studys on the inhibitory effects of Korean medicinal plants and their main compounds on the 1,1-diphenyl-2- picrylhydrazyl radical. Phytomedicine, 10:544-551.

Close, N., Hering, B. and Eggerman, T.(2005).Results from the inaugural year of the Collaborative Islet Transplant Registry. Transplantation Proceedings, 37(2):1305-1308.

Cooke, D.W., and Plotnick, L.(2008). Type 1 diabetes mellitus in pediatrics. Pediatrics in Review, 29 (11): 374-384.

Craig,C.R. and Stitzel, R.E.(1997). Modern Pharmacology with Clinical Application. 5thEdition.Philadephia: Lippincott Publishers Inc.., pp. 763-776.

Craighead, J. E.(1978).Current views on the etiology of insulin-dependent diabetes mellitus. New England Journal of Medicine, 299: $1439-1445$.

Davis, N., Forbes, B., and Wylie-Rosett, J.(2009).Nutritional strategies in type 2 diabetes mellitus. Mount Sinai Journal of Medicine, 76 (3): $257-268$.

Davis, S. N., Butler, P.C., and Brown, M.(1991).The effect of human proinsulin on glucose turnover and intermediary metabolism. Metabolism, 40 : $953-961$.

De Meyts, P.(1994).The structural basis of insulin and insulin-like growth factor-I receptor binding and negative co-operativity, and its relevance to mutagenic versus metabolic signaling. Diabetologia, 37:135-148.

DeFronzo, R.A., and Goodman, A.M.(1995).Efficacy of metformin in patients with non-insulin-dependent diabetes mellitus. The Multicenter Metformin Study Group. New England Journal of Medicine, 333:541-549.

DeLisa, F. and Noel, R. R.(2002). Type 1 diabetes: Virus infection or? Nature Immunology, 3:338-340

Deo, A. and Satri, N.V.(2003).Purification and characterization of polygalacturonase inhibitory effect.

Essential Oil Research, 6(5): 481-483.

Donner, H., Rau, H., Walfish, P.G., Braun, J., Siegmund, T., Finke, R., Herwig, J., Usadel, K.H. and Badenhoop, K.(2007). CTLA4 alanine-17 confers genetic susceptibility to Graves' disease and to type 1 diabetes mellitus. Journal of Clinical Endocrinology \& Metabolism, 82, 1143-1146.

Ebelt, H., Peschke, D., Bromme, H.J., Morke, W., Blume, R. and Peschke, E.(2000). Influence of melatonin on free radical-induced changes in rat pancreatic betacells in vitro. Journal of Pineal Research, 28:65-72.

Page $12 / 21$ 
Elliott, R.B., Pilcher, C.C., Fergusson, D.M. and Stewart, A.W.(1996). A population-based strategy to prevent insulin-dependent diabetes using nicotinamide. Journal of Pediatric Endocrinology and Metabolism, 9(5):501-509.

Elsner, M., Tiedge, M., Guklbakke, B., Munday, R., and Lenzen, S. (2002).Importance of the GLUT2 glucose transporter for pancreatic beta-cell toxicity of alloxan. Diabetologia, 45:1542-1549.

Estadella, D. Oyama, L.M., Damaso, A.R., Ribeiro, E.B., and Oller do Nascimento, C.M. (2004).Effect of palatable hyperlipidemic diet on lipid metabolism of sedentary and exercised rats. Nutrition, 20(2):218- 224.

Etuk, E.U. (2010).Animals models for studying diabetes mellitus. Agricultural and Biology Journal of North America, 1:130-134

Expert Committee on Diabetes,(2003). The Diagnosis and Classification of Diabetes Mellitus Diabetes Care, 26:3160-3167.

Farinazzi-Machado, F.M.V., Guiguer, E.L., Barbalho, S.M., Souza, M., Bueno, P.(2012). The Effect of Psidium guajava leaves on the metabolic profile of Wistar Rats. Journal of Medicinal Plants Research, 6(18):3450-3454.

Farrell, J.B., Deshmukh, A., and Baghaie, A.A.(2008). Low testosterone and the association with type-2 diabetes. The Diabetes Educator, $34(5)$ : 799-806.

Fasanmade, O.A, Odeniyi, I.A. and Ogbera, A.O.(2008). Diabetic ketoacidosis: diagnosis and management. African Journal of Medicine and Medical Sciences, 37(2): 99-105.

Feinglos, M.N. and Angelyn, M.(2008). Type 2 diabetes mellitus: An evidence-based approach to practical management. Totowa, NJ: Humana Press. pp. 462.

Feskanich, D., Ziegler, R.G., Michaud, D.S., Giovannucci, E.L., Speizer, F. E., Willett, W. C. and Colditz, G. A.

(2000).Prospective study of fruit and vegetable consumption and risk of lung cancer among men and women. Journal of the National Cancer Institute, 92:1812-1823.

Fleuriet, A. and Macheix, J.J.(2003).Phenolic acids in fruits and vegetables: Flavonoids in health and disease.New York: Marcel Dekker Inc., pp.43-70.

Frode, T.S. and Medeiros. Y.S.(2008). Animal models to test drugs with potential antidiabetic activity. Journal of Ethnopharmacology, 115:173-183.

Geidam, Y.A., Ambali, A.G. and Onyeyili, P.A.(2007). Phytochemical screening and antibacterial properties of organic solvent fractions of Psidium guajava aqueous leaf extracts. International Journal of Pharmacology, 3(1):68-73.

Gorus, F.I.C, Malaise, W.J, and Pipeleers, D.G.(1982).Selective uptake of alloxan by pancreatic B-cells.

Biochemistry Journal, 208:513-515.

Gutiérrez, R.M., Mitchell, S. and Solis, R.V. (2008). Psidium guajava: A review of its traditional uses, phytochemistry, and pharmacology. Journal of Ethnopharmacology, 117:1-27.

Haida, K.S., Baron, A., Haida, K.S., Faci, D., Haas, J., Silva, F.J.(2011). Phenolic Compounds and Antioxidant activity of two varieties of guava and rue. Revista Brasileira de Ciências da Saúde, 28:11-19.

Halliwell, B.(1996).Antioxidants in human health and disease. Annual Review of Nutrition, 16:33-50. Harborne J. B,(1998). Phytochemical methods, a guide to modern techniques of plant analysis, 3rd edition, New Delhi: Springer (India) Pvt. Ltd, pp. 4-30

Harborne, J. B.(1973). Phytochemical Method: A Guide to Modern Techniques of Plant Analysis. Chapman and Hall, New York. pp 40-278.

Herder C. and Roden M.(2011).Genetics of type 2 diabetes: Pathophysiologic and clinical relevance. European Journal of Clinical Investigation, 41 (6): 679-692.

Hirsch, I.B.(2005). Insulin analogs. New England Journal of Medicine, 352:174-183.

Hsieh, C.L., Lin, Y.C., Ko, W.S., Peng, C.H., Huang, C.N. and Peng, R.Y.(2005). Inhibitory effect of some selected nutraceutical herbs on LDL glycation induced by glucose and glyoxal. Journal of Ethnopharmacology, 102: 357-363.

Hu, E.A., Pan A., Malik V., and Sun Q.(2012).White rice consumption and risk of type 2 diabetes: a meta- analysis and systematic review. British Medical Journal, 344: 1454-1460.

Hyppönen, E., Läärä, E., Reunanen, A., Järvelin, M. R. and Virtanen, S.M. (2001). Intake of vitamin D and risk of type-1 diabetes: a birth cohort study. Lancet, 358(9292):1500-1503.

International Expert Committee(2009).International Expert Committee report on the role of the HbA1C assay in the diagnosis of diabetes. Diabetes Care, 32(7): 1327-1334.

Ishida, Y.(2001). Food for specified health uses. FOSHU in primary care of lifestyle-related disease (disorders) with foods, Tokyo. Dai-ichi Shuppan Hosoya, 1:176-178. 
Izzedine, H., Launay-Vacher, V., Deybach, C., Bourry, E., Barrou, B. and Deray, G.(2005). Drug-induced Diabetes Mellitus. Expert Opinion on Drug Safety, 4(6):1097-109.

Jimenez-Escrig, A., Rincon, M., Pulido, R. and Saura-Calixo, F.(2001). Guava fruit(Psidium guajava L.) is a new source of antioxidant dietary fiber. Journal of Agriculture and Food Chemistry, 49(11): 5489-5493.

Joseph, B. and Mini, P.R.(2011). Review on nutritional, medicinal, and pharmacological properties of guava (Psidium guajava Linn.). International Journal of Pharma and Bio Sciences, 2(1):54-69.

Kaplan, N.M.(1989). The Deadly Quartet: Upper-body obesity, glucose intolerance, hypertriglyceridemia, and hypertension. Archives of Internal Medicine,149:1514-1520.

Katzung, B., Masters, S. and Trevor, A.(2012).Basic and clinical pharmacology, 12th Edition. England: Lange publishers Ltd, pp. 785-1012.

Kliber, A., Szkudelski, T. and Chichlowska, J.(1996).Alloxan stimulation and subsequent inhibition of insulin release from in situ perfused rat pancreas.Journal of Physiology and Pharmacology, 47:321-328.

Knip, M., Veijola, R., Virtanen, S. M., Hyoty, H., Vaarala, O., and Akerblom, H. K.(2005).Environmental Triggers and Determinants of Type 1 Diabetes. Diabetes Care, 54: 125136.

Koo, M. H., and Mohamed, S. (2001). Flavonoid (myricetin, quercetin, kaempferol, luteolin, and apigenin)content of edible tropical plants. Journal of Agricultural and Food Chemistry, 49:3106-3112.

Kumar, V., Fausto, N., Abbas, A. K., Cotran, R. S. and Robbins, S. L. (2005).Robbins and Cotran Pathologic Basis of Disease, 7th edition. Philadelphia, Pa.: Saunders publishers Ltd., pp. 1194-1195.

Lachin, T. and Reza, H.(2012). Antidiabetic effect of cherry in alloxan-induced diabetic rats. Recent Patents on Endocrine, Metabolism and Immune Drug Discovery, 6:67-72.

Lakey, J., Burridge, P. and Shapiro, A.(2003).Technical aspects of islet preparation and transplantation.

Transplant International Journal, 16(9): 613-632.

Lapik, O., Klejdus B. and Kokoska L.(2005).Identification of isoflavones in Acca sellowiana and two Psidium species (Myrtaceae).Biochemical Systematics and Ecology, 33: 983-992.

Larsen, L.L. (2004). Pancreas transplantation: Indicators and consequences. Endocrine Reviews, 25(6):919-925

Lee, I.M., Shiroma, E. J., Lobelo, F., Puska, P., Blair, S. N and Katzmarzyk, P. T.(2012). Effect of physical inactivity on major non-communicable diseases worldwide: An analysis of burden of disease and life expectancy. The Lancet, 380(9838): 219-229.

Lenzen, S. and Munday, R.(1991).Thiol-group reactivity, hydrophilicity, and stability of alloxan, its reduction products, and its N-methyl derivatives and a comparison with ninhydrin. Journal of Biochemical Pharmacology, 42:1385-1391.

Lenzen, S.(2008).The mechanisms of alloxan and streptozotocin-induced diabetes. Diabetologia, 51:216-226.

Lewis, G.F., Carpentier, A., Khosrow, A. and Giacca, A. (2002). Disordered fat storage and mobilization in the pathogenesis of insulin resistance and type 2 diabetes. Endocrine Reviews, 23: 201-229.

Lincy, J. G. M., Singh, G., Mathews, P.(2016) Phytochemical investigation on various parts of Psidium guajava.

International Journal for Pharmaceutical Research Scholars, 1:102-107.

Liu, R.H.(2004).Potential synergy of phytochemicals in cancer prevention: Mechanism of action. Journal of Nutrition, 134: $3479-3485$.

Lorke D. (1983).A new approach to practical acute toxicity testing. Archives of Biochemistry and Biophysics, 225:175-270.

Lozoya, X., Reyes-Morales, H, Chavez-Soto, M., Martinez-Garcia, M.C., Soto-Gonzalez, Y. and Doubova, S.V.(2002).Intestinal antispasmodic effect of a phytodrug of Psidium guajava folia in the treatment of acute diarrheic disease.Journal of Ethnopharmacology,83: $19-24$.

Lutterodt, G. D. (1989).Inhibition of gastrointestinal release of acetylcholine by quercetin as a possible mode of action of Psidium guajava leaf extracts in the treatment of acute diarrhoeal disease. Journal of Ethnopharmacology, 25(3):235-247.

Malcova, H., Sumnik, Z., Drevinek, P., Venhacova, J. and Lebl, J. (2006) Absence of breastfeeding is associated with the risk of type 1 diabetes: A casecontrol study in a population with rapidly increasing incidence. European Journal of Pediatrics, 165:114-119.

Malik, V.S., Popkin, B.M., Bray, G.A., Després, J.P. and Hu, F.B. (2010a).Sugar-sweetened beverages, obesity, type-2 diabetes, and cardiovascular disease risk. Circulation, 121(11):1356-64. 
Malik, V.S., Popkin, B.M., Bray, G.A., Després, J.P., Willett, W.C. and Hu, F.B. (2010b). Sugar-Sweetened- beverages and risk of metabolic syndrome and type 2 diabetes: A meta-analysis. Diabetes Care,33(11):2477-83.

Matsuo, T., Hanamure, N. Shimoi, K., Nakamura, Y. and Tomita I. (1994).Identification of (+)gallocatechin as a bio-antimutagenic compound in Psidium guava leaves. Phytochemistry, 36(4): 1027-1029.

Matsuzawa, Y.(1997).Pathophysiology and molecular mechanisms of the visceral fat syndrome: The Japanese experience. Diabetes Metabolism Research and Reviews,13:3-13.

McBrien, K., Rabi, D.M., Campbell, N., Barnieh, L., Clement, F., Hemmelgarn, B.R., Tonelli, M., Leiter, L.A., Klarenbach, S.W. and Manns, B.J.(2012). Intensive and standard blood pressure targets in patients with type 2 diabetes mellitus: Systematic review and meta-analysis.Archives of Internal Medicine, 172(17):1-8.

Melmed, S., Polonsky, K., Reed Larsen, P. and Kronenberg, H. P.(2011). Williams's textbook of endocrinology, 12th Edition. Philadelphia: Elsevier/Saunders. pp. 1371-1435.

Narayana, K.R., Reddy, M.S., Chaluvadi, M.R. and Krishna, D.R.(2001).Bioflavonoids: Classification, pharmacology, biochemical effects, and therapeutic potential. Indian Journal of Pharmacology, 33:2- 16.

Nield, L., Summerbell, C.D., Hooper, L., Whittaker, V., and Moore, H.(2008).Dietary advice for the prevention of type 2 diabetes mellitus in adults: In Nield Lucie. Cochrane Database of Systematic Review,3:5-102.

Norazmir, M.N. and Ayub, M.Y. (2010).Beneficial lipid-lowering effects of pink guava puree in high-fat diet induced obese rats. Malaysian Journal of Nutrition, 16(1): $171-185$

Nwinyi, O.C., Chinedu, N.S., and Ajani, O.O.(2008).Evaluation of the antibacterial activity of Psidium guajava and Gongronema latifolium. Journal of Medicinal Plants Research, 2(8):189-192.

Nzi, A.K., Elfriede, M.B., Nilton, L., Soraya, D. and Varela, E.A.(2007). Acute, sub-acute toxicity and genotoxic effect of a hydroethanolic extract of cashew (Anacardium occidentale L.). Journal of Ethnopharmacology, 110:30-38.

O'Gorman, D.J., and Krook, A.(2011).Exercise and the treatment of diabetes and obesity. The Medical clinics of North America, 95(5): 953-969.

Ojewole, J.A.(2005). Hypoglycaemic and hypotensive effects of Psidium guajava Linn.(Myrtaceae) leaf aqueous extract. Methods and Findings in Experimental and Clinical Pharmacology, 27(10): 689-695.

Olajide, O. A., Awe, S. O., and Makinde, J. M.(1999). Pharmacological studies on the leaves of Psidium guajava.

Fitoterapia, 70:25-31.

Orozco, L.J., Buchleitner, A.M., Gimenez-Perez, G., Roqué, I., Figuls, M., Richter.B. and Mauricio, D.(2008). Exercise or exercise and diet for preventing type 2 diabetes mellitus. Cochrane Database of Systematic Reviews,3:003-054.

Park, B.H., Rho, H.W., Park, J.W., Cho, C.G., Kim, J.S., Chung, H.T. and Kim, H.R.(1995). Protective mechanism of glucose against alloxan-induced pancreatic beta-cell damage. Biochemical Biophysical Research Communications, 210:1-6.

Pasquier F. (2010).Diabetes and cognitive impairment: How to evaluate the cognitive status. Diabetes and Metabolism, 36(3): $100-105$.

Pociot, F. and McDermott, M.(2002).Genetics of type 1 diabetes mellitus. Genes and Immunity, 3:235-249.

Rai, P.K., Mehta, S. and Watal, G.(2010). Hypolipidaemic and hepatoprotective effects of Psidium guajava raw fruit peel in experimental diabetes. Indian Journal of Medical Research, 131:820-824.

Raina, E.C., and Kenealy, T.(2008). Lifestyle interventions reduced the long-term risk of diabetes in adults with impaired glucose tolerance. Evidence-Based Medicine, 13(6):173-176.

Ram, B.S., Shanti, S.R., Reema, S., Saraswati, G. and Mohammad A.N.(1992).Effect of guava intake on serum total and highdensity lipoprotein cholesterol levels and systemic blood pressure. The American Journal of Cardiology, 15:1287-1291.

Raptis, S.A. and Dimitriadis, G.D.(2001). Oral hypoglycemic agents: Insulin secretagogues, alpha-glucosidase inhibitors, and insulin sensitizers. Experimental and Clinical Endocrinology and Diabetes, 109(2):265- 287.

Reaven, G.M.(1988).Role of insulin resistance in human disease. Diabetes Care, 2(37):1595-1607.

Ripsin, C.M., Kang, H., and Urban, R.J.(2009).Management of blood glucose in type 2 diabetes mellitus. 
American Family Physician, 79(1): 29-36.

Risérus, U., Willett, W.C. and Hu, F.B.(2009).Dietary fats and prevention of type 2 diabetes. Progress in Lipid Research, 48 (1): $44-51$.

Roa, E.(2000).Intestinal absorption of triglyceride and cholesterol: Dietary and pharmacological inhibition to reduce cardiovascular risk. Atherosclerosis, 151:357-379.

Roy, C.K., Kamath, J.V., and Asad, M.(2006). Hepatoprotective activity of Psidium guajava L. leaf extract.

Indian Journal of Experimental Biology, 44(4): 305-311.

Saad, F. and Gooren, L.(2009). The role of testosterone in the metabolic syndrome: A review. The Journal of Steroid Biochemistry and Molecular Biology, 114(12): 40-43.

Sakurai, K. and Ogiso, T.(1995). Effect of ferritin on DNA strand breaks in the reaction system of alloxan plus NADPH cytochrome P450 reductase: Ferritin's role in diabetogenic action of alloxan.Biological Pharmaceutical Bulletin, 18:262-266.

Sampson, U.K., Linton, M.F. and Fazio, S.(2011).Are statins diabetogenic? Current Opinion in Cardiology, 26(4): 342-347.

Santaguida, P.L., Balion, C. and Hunt, D.(2005). Diagnosis, prognosis, and treatment of impaired glucose tolerance and impaired fasting glucose. Evidence Report/Technology Assessment (Summary), 128: 1- 11.

Saydah, S.H., Miret, M., Sung, J., Varas, C., Gause, D. and Brancati, F.L.(2001).Post challenge hyperglycemia and mortality in a national sample of U.S. adults. Diabetes Care, 24(8): 1397-1402.

Schellenberg, E.S., Dryden, D.M., Vandermeer, B., Ha, C. and Korownyk, C.(2013). Lifestyle Interventions for Patients With and at Risk for Type 2 Diabetes: A systematic review and meta-analysis. Annals of Internal Medicine, 159(8): 543-51.

Shi, H. L., Noguchi, N. and Niki, E.(2001).Introducing natural antioxidants. Antioxidants in Food: Practical Applications. Cambridge: Woodhead Publishing Ltd and CRC Press. P.p 30-38.

Shinha, S., Mukherjee, P.K., Mukherjee, K., Pal, M., Mandal, S.C. and Saha, B.P.(2000).Evaluation of the antipyretic potential of Nelumbo nucifera stalk extract. Phytotherapy Research, 14:272-274.

Shoback, D. and Gardner, D. G.(2011). Greenspan's Basic and Clinical Endocrinology, 9th edition, New York: McGraw-Hill Medical Publishers Ltd. pp. 643-648.

Shu, J., Chou, G. and Wang, Z. (2010).Two new benzophenone glycosides from the fruit of Psidium guajava

L. Fitoterapia, 81:532-535.

Singh, R.B., Rastogi, S.S., Singh, N.K., Ghosh, S. and Niaz, M.A.(1992).Effects of guava intake on serum total and high-density lipoprotein cholesterol levels and systemic blood pressure. American Journal of Cardiology, 70(15): 1287-1291

Singh, R.B., Rastogi, S.S., Singh, N.K., Ghosh, S., Gupta, S., and Niaz, M.A. (1993). Can guava fruit intake decrease blood pressure and blood lipids? Journal of Human Hypertension, 7(1): 33-38.

Smith, R.M. and Siwatibau S.(1975). Sesquiterpene hydrocarbons of Fijian guavas. Phytochemistry, 14:2013-2015.

Sofowora A.(1993).Medicinal plants and traditional medicine in Africa. Spectrum books limited, lbadan, Nigeria, pp.191-289.

Szkudelski, T.(2001).The mechanism of alloxan and streptozotocin action in B cells of the rat pancreas.

Physiological Research, 50:536-546.

Szkudelski, T., Kandulska, K. and Okulicz, M.(1998). Alloxan in vivo does not only exert deleterious effects on pancreatic B cells. Physiological Research, 47:343-346.

Thomas, D. and Elliott, E.J.(2009).Low glycaemic index or low glycaemic load diets for diabetes mellitus.

Cochrane Database of Systematic Review, 1:006-296.

Trease, G.E. and Evans, M.C.(1983). Textbook of Pharmacognosy,13th edition. Bailiere: Tindall Publishers Ltd, pp $2000-2775$.

Trinder P.(1969).Determination of glucose in blood using glucose oxidase with an alternative oxygen acceptor.

Page 16/21 
Annals of Clinical Biochemistry, 6:24-27.

Tripathi, R.N., Tripathi, R.K.R. and Pandey, D.K.(1981). Assay of antiviral activity in the crude leaf sap of some plants. Indian Journal of Environmental Biological Science, 4:86-87.

United States Department of Agriculture, Natural resources Conservation Service(2013). Classification of kingdom Plantae down to genius Psidium L. retrieved on 14th February 2017 via www.usanrcs.gov.us

Vijan, S.(2010).Type 2 diabetes. Annals of Internal Medicine, 152(5): 1-15.

Virtanen, S.M. and Knip, M.(2003). Nutritional risk predictors of beta-cell autoimmunity and type 1 diabetes at a young age. The American Journal of Clinical Nutrition, 78(6): 10531067.

Wei L., Li Z., and Chen B.(2000).Clinical study on treatment of infantile rotaviral enteritis with Psidium guajava L. Chinese Journal of Modern Developments in Traditional Medicine, 20(12): 893-895.

Weigle, D.S. (2003). Pharmacological therapy of obesity: past, present, and future. Journal of Clinical Endocrinology and Metabolism, 88(6):2462-2469.

Wild, S., Roglic, G., Green, A., Sicree, R., and King, H.(2004). The global prevalence of diabetes: Estimates for the year 2000 and projections for 2030 . Diabetes Care, 27(5):1047-1053.

World Health Organization(2006). Definition and diagnosis of diabetes mellitus and intermediate hyperglycemia: Report of a WHO/IDF consultation, Geneva, p. 21.

Wright, J.R.(2002). In From Ugly Fish to Conquer Death: JJrMacleod's fish insulin. The Lancet, 359(9313):1238- 1242.

Yamashiro, S., Noguchi, K. and Matsuzaki, T.(2003). Cardioprotective effects of extracts from Psidium guajava L and Limonium wrightii Okinawan medicinal plants against ischemic perfusion injury in perfused rat hearts. Journal of Pharmacology, 67: 128-135.

Zanuso, S., Jimenez, A., Pugliese, G., Corigliano, G. and Balducci, S.(2010). Exercises for the management of type 2 diabetes: A review of the evidence. Acta Diabetologica, 47(1): 1522.

Zhang, H., Zdolsek, J.M. and Brunk, U.T.(1992). Alloxan cytotoxicity involves lysosomal damage. Acta Pathologica, Microbiologica et Immunologica Scandinavica, 100:309-316

\section{Figures}

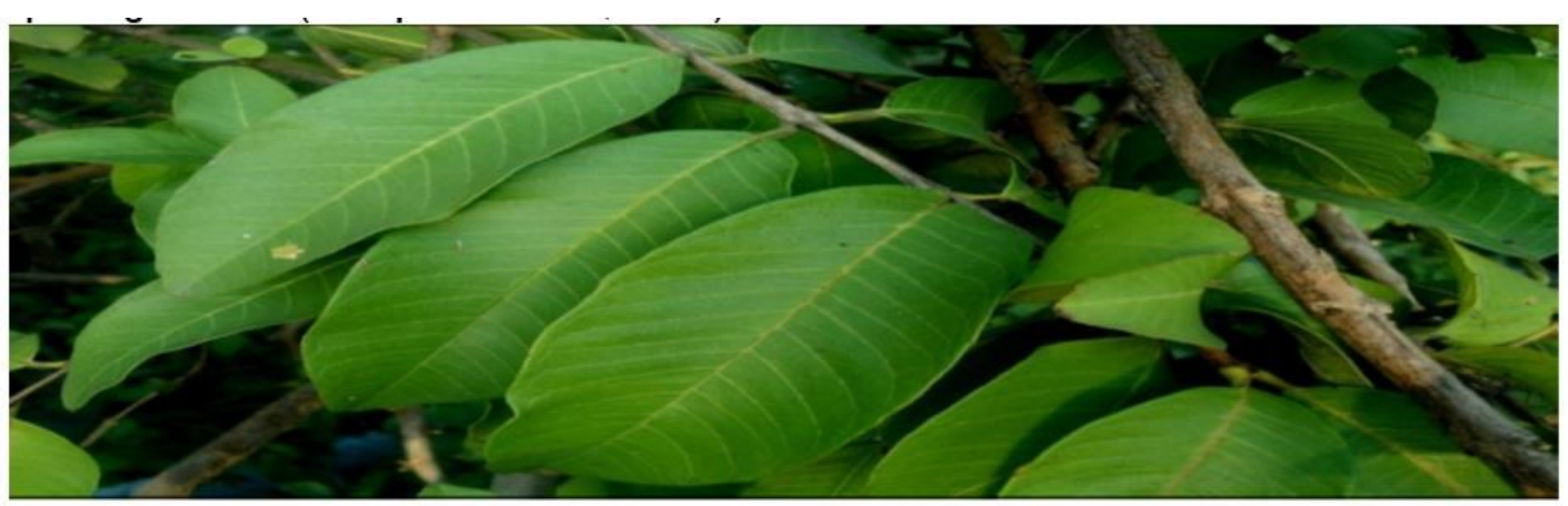

\section{Figure 1}

Figure 1.1: Structure of guava leaves Source: United States Department of Agriculture; Natural Resources Conservation Service, 2013. Taxonomic Classification of Psidium guajava Linnaeus. Kingdom: Plantae Sub kingdom: Viridaephytae (green plants) Infra kingdom: Streptophytae (land plants) Division: Tracheophyta (vascular plants) Subdivision: Spermatophyta (seed plants) Infra division: Angiospermae (flowering plants) Class: Magnoliopsida (dicotyledons) Superorder: Rosidae Order: Myrtales Family: Myrtaceae Genius: Psidium Linnaeus Species: guajava Linnaeus Variety: Psidium guajava pyrifera (white guava) 


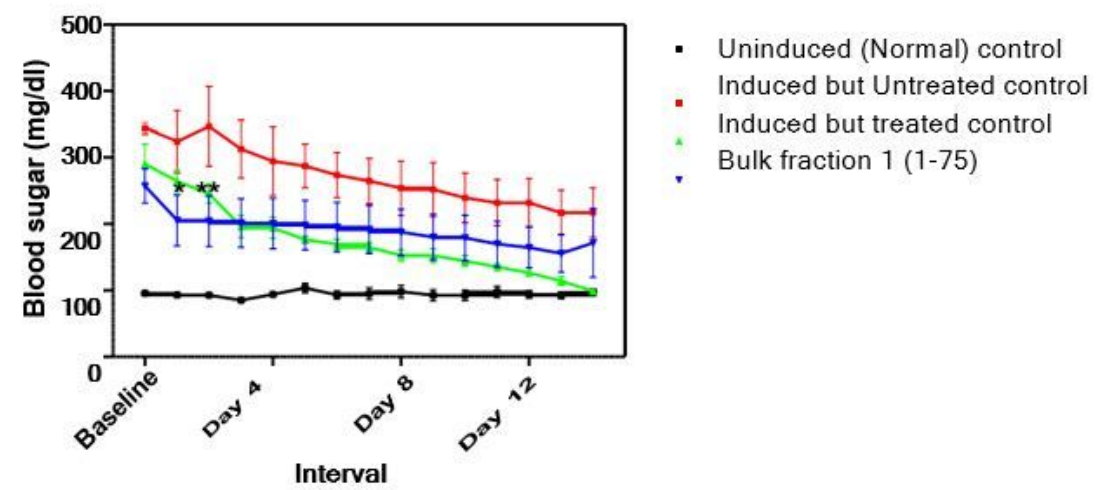

Figure 2

Figure 3.3.1: Blood sugar measurements of alloxan-induced diabetic mice treated with Bulked Fraction, EF-I (1-75) (100mg/kg b.w) of Psidium guajava Ethyl Acetate Crude Leaf Extract.

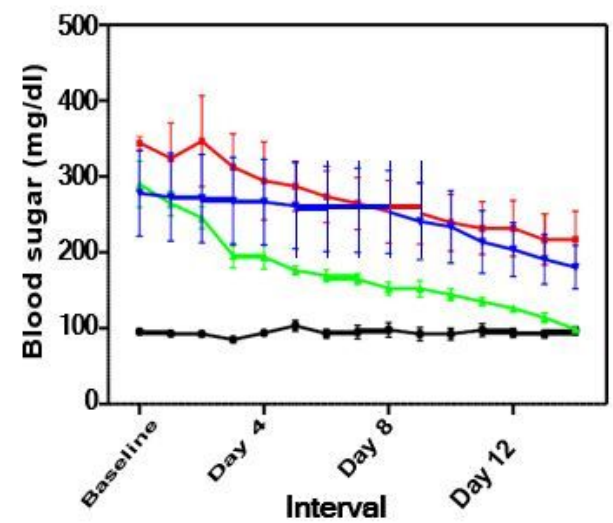

Uninduced (Normal) control Induced but Untreated control Induced but treated control Bulk fraction II (76-150)

Figure 3

Figure 3.3.2: Blood sugar measurements of alloxan-induced diabetic mice treated with Bulked Fraction, EF-II (76-150) (100mg/kg b.w) of Psidium guajava Ethyl Acetate Crude Leaf Extract.

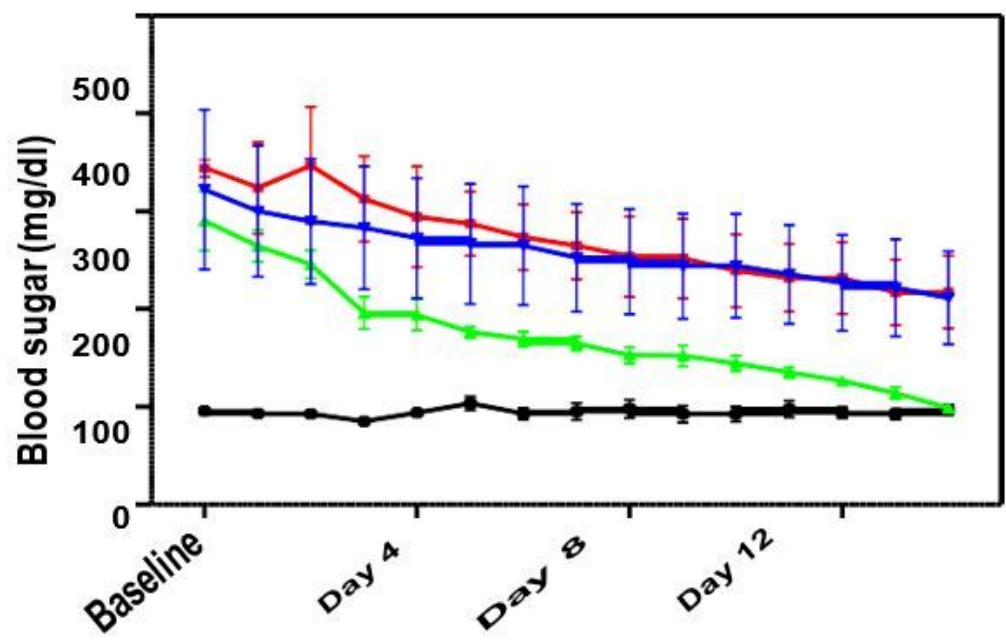

Uninduced (Normal) control Induced but Untreated control Induced but treated control Bulk fraction III (151-250) 
Figure 4

Figure 3.3.3: Blood sugar measurement of alloxan-induced diabetic mice treated with Bulked Fraction, EF-III (151-250) (100mg/kg b.w) of Psidium guajava Ethyl Acetate Crude Leaf Extract.

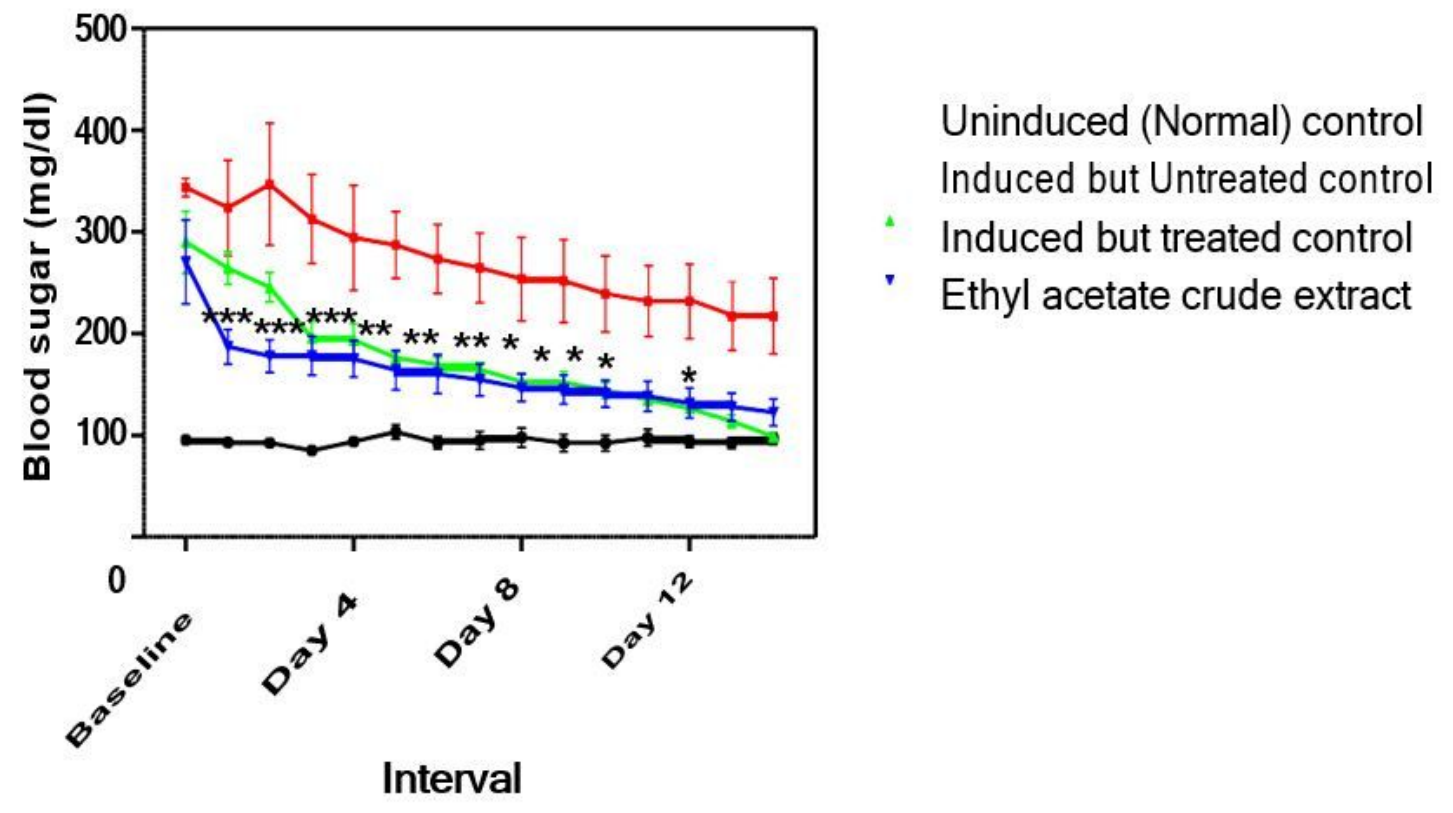

Figure 5

Figure 3.4.1: Blood sugar measurements of alloxan-induced diabetic mice treated with Ethyl Acetate Crude Leaf Extract (100mg/kg b.w) of Psidium guajava.

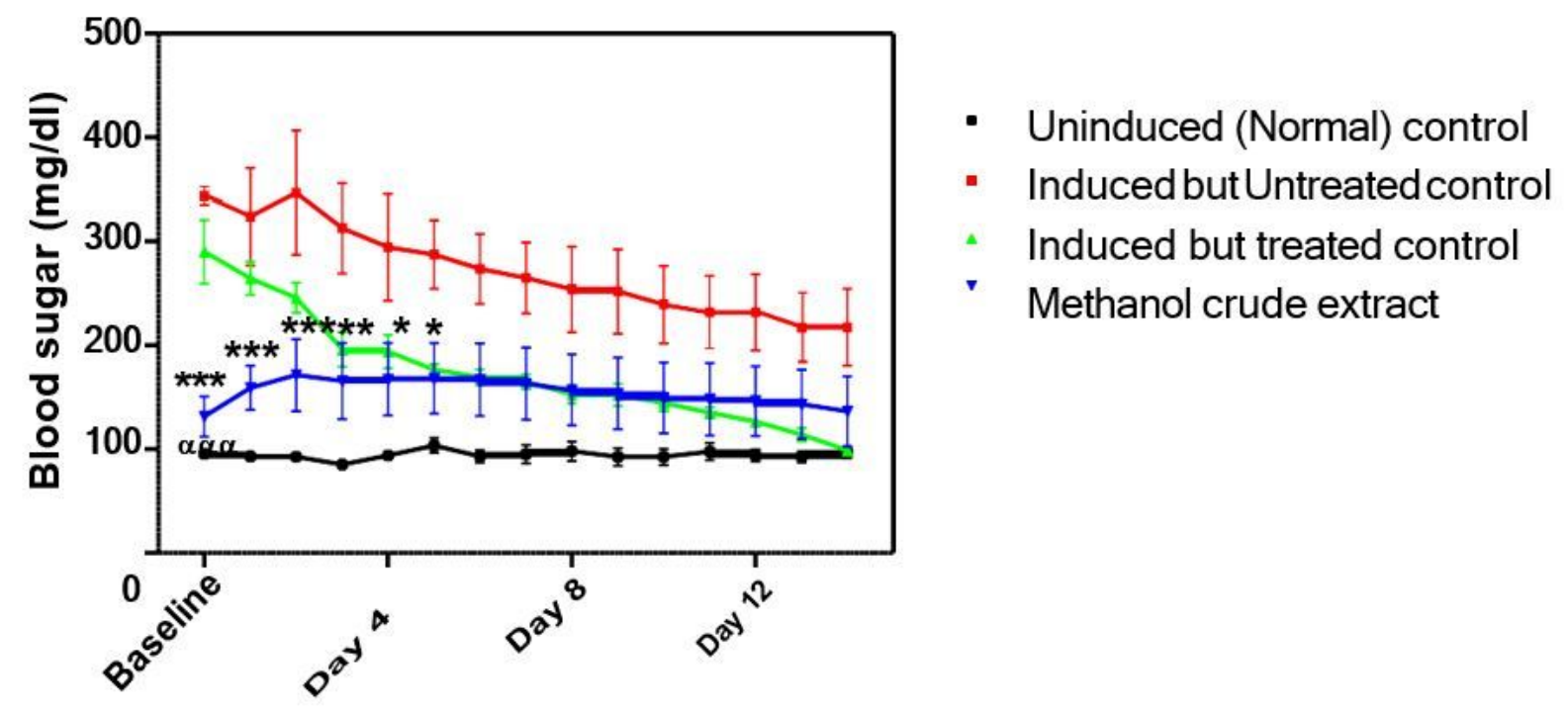

Interval

Figure 6

Figure 3.4.2: Blood sugar measurements of alloxan-induced diabetic mice treated with Methanol Crude Leaf Extract (100 mg/kg b.w) of Psidium guajava. 


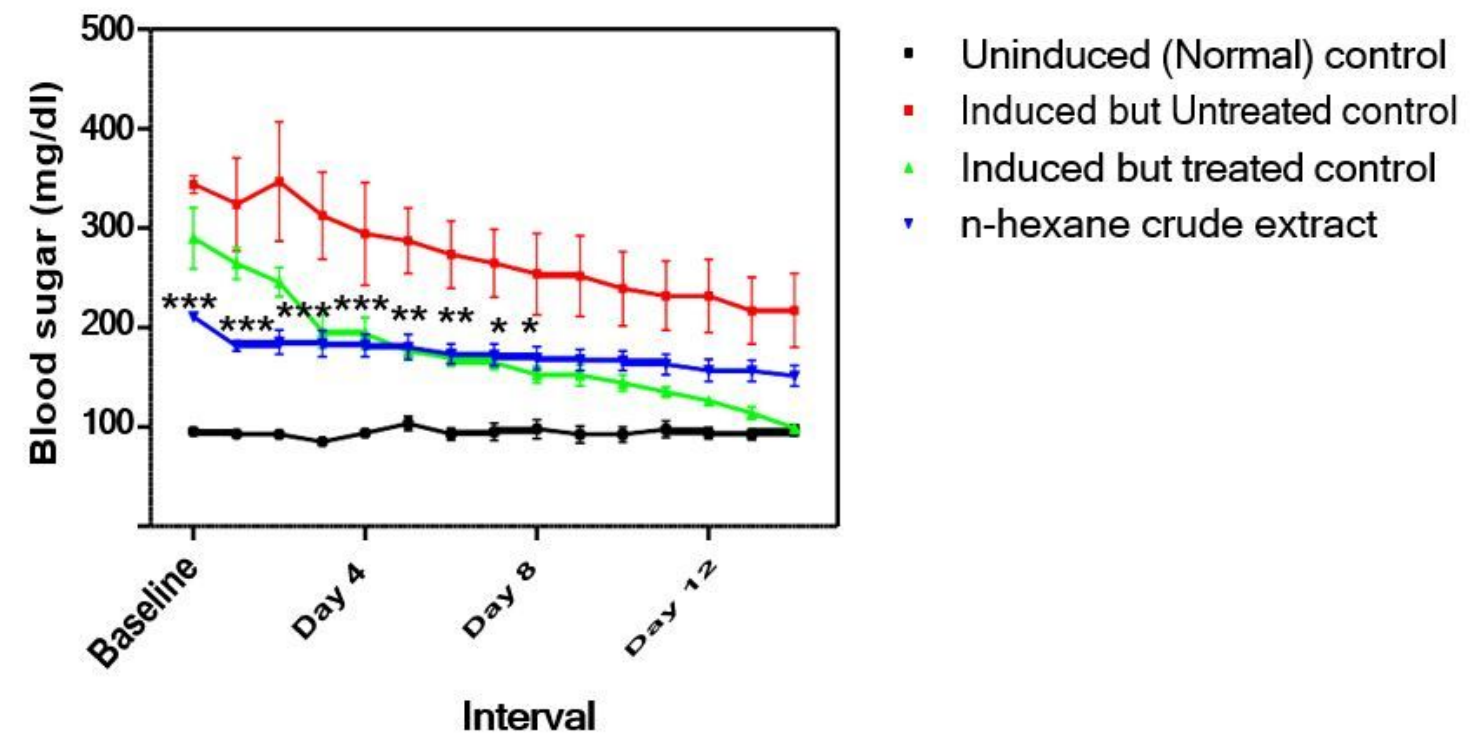

Figure 7

Figure 3.4.3: Blood sugar measurements of alloxan-induced diabetic mice treated with n-Hexane Crude Leaf Extract (100 mg/kg b.w) of Psidium guajava
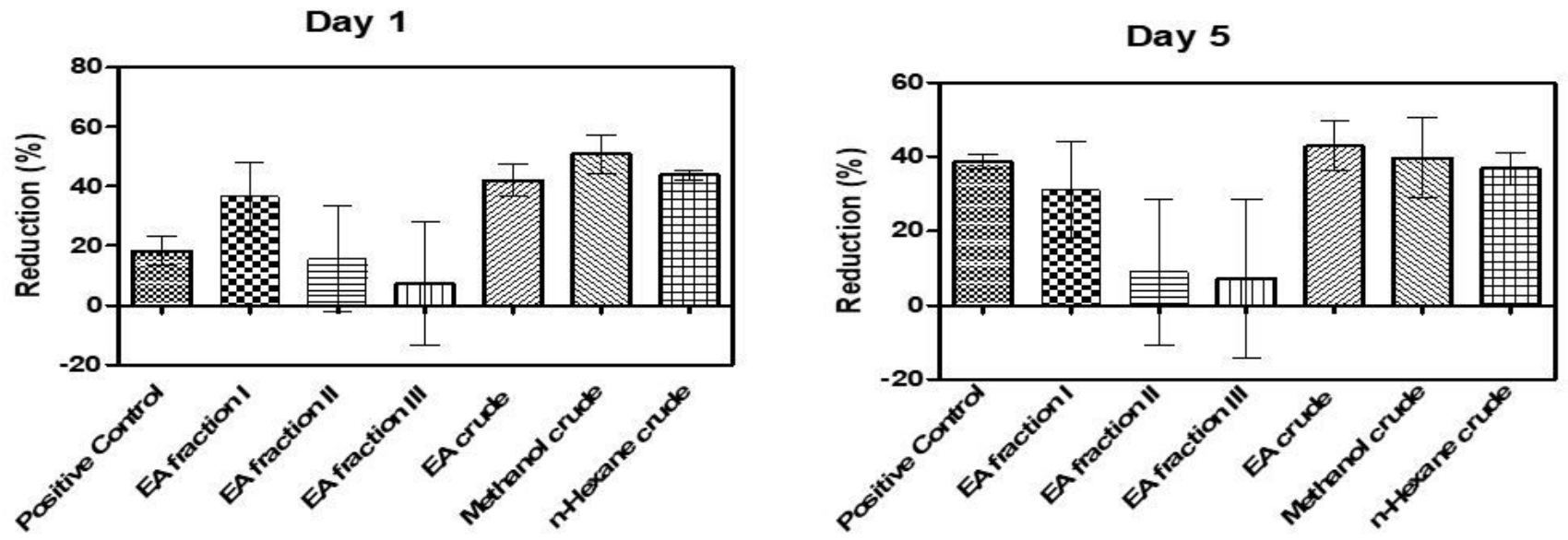

Figure 8

Figure 3.5.1(A and B): Percentage reduction of Blood sugar (mean \pm SEM) on First (1st) and Fifth (5th) treatment days. Each bar represents the mean percentage reduction. (Error bars are the standard error of the mean (SEM). Each bar was not significantly different from the positive control. (One-way ANOVA with Dunnett's multiple comparisons, using Graph pad Prism 5). 
Day 14

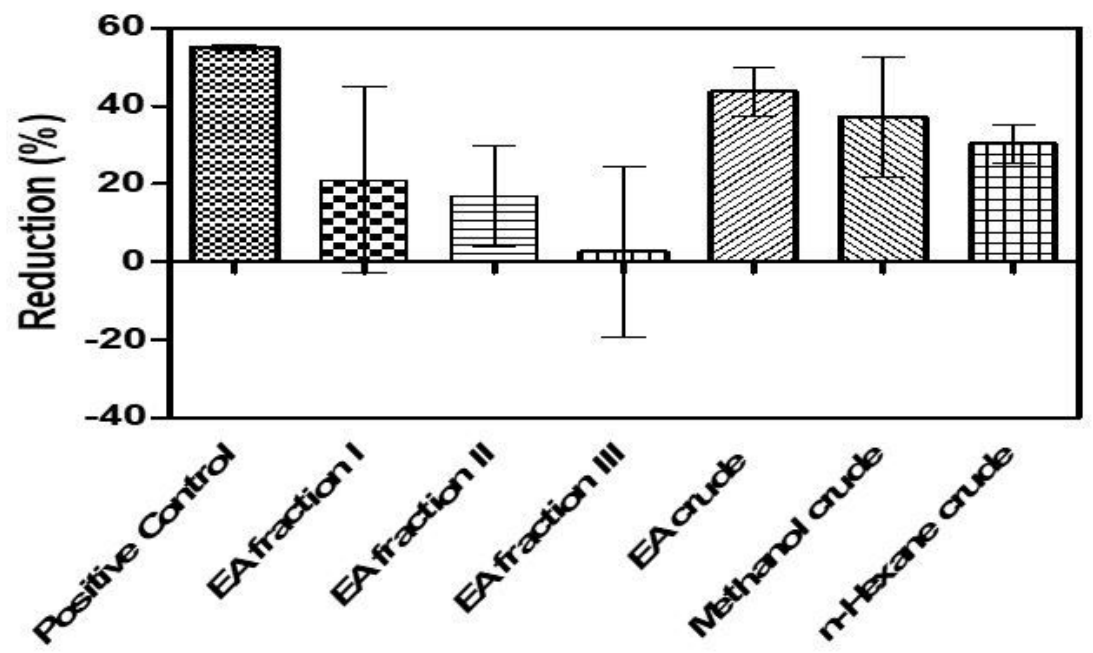

Figure 10

Figure 3.5.3: Percentage reduction of Blood sugar (mean \pm SEM) on Fourteenth (14th) treatment day. Each bar represents the mean percentage reduction; error bars are the standard error of the mean. Each bar was not significantly different from the positive control. (One-way ANOVA with Dunnett's multiple comparisons, using Graph pad Prism 5). 